\title{
Evolution of crab eye structures and the utility of ommatidia morphology in resolving phylogeny
}

\author{
Javier Luque ${ }^{1,2,3^{*}}$, W. Ted Allison ${ }^{2}$, Heather D. Bracken-Grissom ${ }^{4}$, Kelsey M. Jenkins ${ }^{1}$, A.
}

${ }^{1}$ Department of Geology and Geophysics, Yale University, New Haven, CT 06520-8109, USA

${ }^{2}$ Department of Biological Sciences, University of Alberta, Edmonton, Alberta T6G 2E9, Canada

${ }^{3}$ Smithsonian Tropical Research Institute, Balboa-Ancón 0843-03092, Panamá, Panamá

$10{ }^{4}$ Department of Biological Sciences, Florida International University-Biscayne Bay Campus, North

Miami, FL 33181, USA

${ }^{5}$ Department of Biology, University of Hawaii at Manoa, Honolulu, HI 96822, USA

${ }^{6}$ Museum of Comparative Zoology and Department of Organismal and Evolutionary Biology, Harvard

University, Cambridge, MA 02138, USA

15

*Corresponding author. E-mail: javier.luque@yale.edu; 1 luque@ualberta.ca 


\section{ABSTRACT}

20 Image-forming compound eyes are such a valuable adaptation that similar visual systems have evolved independently across crustaceans. But if different compound eye types have evolved independently multiple times, how useful are eye structures and ommatidia morphology for resolving phylogenetic relationships? Crabs are ideal study organisms to explore these questions because they have a good fossil record extending back into the Jurassic, they possess a

25 great variety of optical designs, and details of eye form can be compared between extant and fossil groups. True crabs, or Brachyura, have been traditionally divided into two groups based on the position of the sexual openings in males and females: the so-called 'Podotremata' (females bearing their sexual openings on the legs), and the Eubrachyura, or 'higher' true crabs (females bearing their sexual openings on the thorax). Although Eubrachyura appears to be monophyletic, the monophyly of podotreme crabs remains controversial and therefore requires exploration of new character systems. The earliest podotremous lineages share the plesiomorphic condition of 'mirror' reflecting superposition eyes with most shrimp, lobsters, and anomurans (false crabs and allies). The optical mechanisms of fossil and extant podotreme groups more closely related to Eubrachyura, however, are still poorly investigated. To better

35 judge the phylogenetic utility of compound eye form, we investigated the distribution of eye types in fossil and extant podotreme crabs. Our findings suggest the plesiomorphic 'mirror' eyes - seen in most decapod crustaceans including the earliest true crabs-has been lost in several 'higher' podotremes and in eubrachyurans. We conclude that the secondary retention of larval apposition eyes has existed in eubrachyurans and some podotremes since at least the

40 Early Cretaceous, and that the distribution of eye types among true crabs supports a paraphyletic podotreme grade, as suggested by recent molecular and morphological phylogenetic studies. We also review photoreceptor structure and visual pigment evolution, currently known in crabs exclusively from eubrachyuran representatives. These topics are critical for future expansion of research on podotremes to deeply investigate the homology of 45 eye types across crabs.

Keywords: Apposition; Brachyura; Cretaceous; Cenozoic; exceptional preservation; fossil; Superposition 
Page -3-

\section{INTRODUCTION}

50 True crabs, or Brachyura, are a speciose and economically important group of crustaceans first known from the Early Jurassic, more than 170 Mya (Luque et al., 2019a; Wolfe et al., 2019, and references therein). Their remarkable modern and past diversity of form and adaptations is not restricted to their carapace or limbs (Fig. 1), but also evident in the wide range of compound eye types and underlying visual systems across modern crab taxa (Cronin and Porter, 2008) (Fig. 2).

55 Brachyura are widely recognized as a monophyletic clade (e.g., Rice, 1981; Jamieson et al., 1995; Ahyong et al., 2007; Ng et al., 2008; Scholtz and McLay, 2009; Tsang et al., 2014; Luque et al., 2019a; Wolfe et al., 2019). Yet, their internal relationships are still debated, especially concerning the so-called 'podotreme' crabs (i.e., those crabs where both males and females have coxal sexual openings, Fig. 3A), and how they relate to Eubrachyura or 'higher' crabs, with

60 sexual openings on the coxa of males and the thorax in females (i.e., Heterotremata, Fig. 3B), or thoracic in both males and females (i.e., Thoracotremata, Fig. 3C).

The lack of agreement about how podotremes relate to each other and to eubrachyurans has profound effects on our understanding of the evolution of true crabs (Luque et al., 2019a), and therefore any potential phylogenetic significance that a given eye type, and therefore its facet

65 shape and packing, may have (Fig. 4). Although closely related groups would be expected to share similar visual systems and facet shapes/packing, no work has investigated the distribution of eye types across crabs in a phylogenetic context to date, neither whether the morphology of their ommatidia is useful to infer underlying eye types, and especially, what does the fossil record tell about the distribution of facet shape and packing across crabs through time.

\section{Basic eye types in crabs}

Currently, there are four main types of compound eyes recognized in crustaceans: apposition, parabolic superposition, refracting superposition, and reflecting superposition, each one with its particular combination of external and internal features (Land, 1976; Nilsson, 1988; Gaten, 1998;

75 Cronin and Porter, 2008) (Fig. 2). Apposition eyes are the simplest (Fig. 2A). In this eye type, isolated ommatidia with hexagonal facets are packed in a hexagonal lattice, and functions best in relatively bright light. They are the ancestral condition for crustaceans and present in the larval stages of all decapods (Land, 1980; Fincham, 1984; Porter and Cronin, 2009) (Fig. 5). 

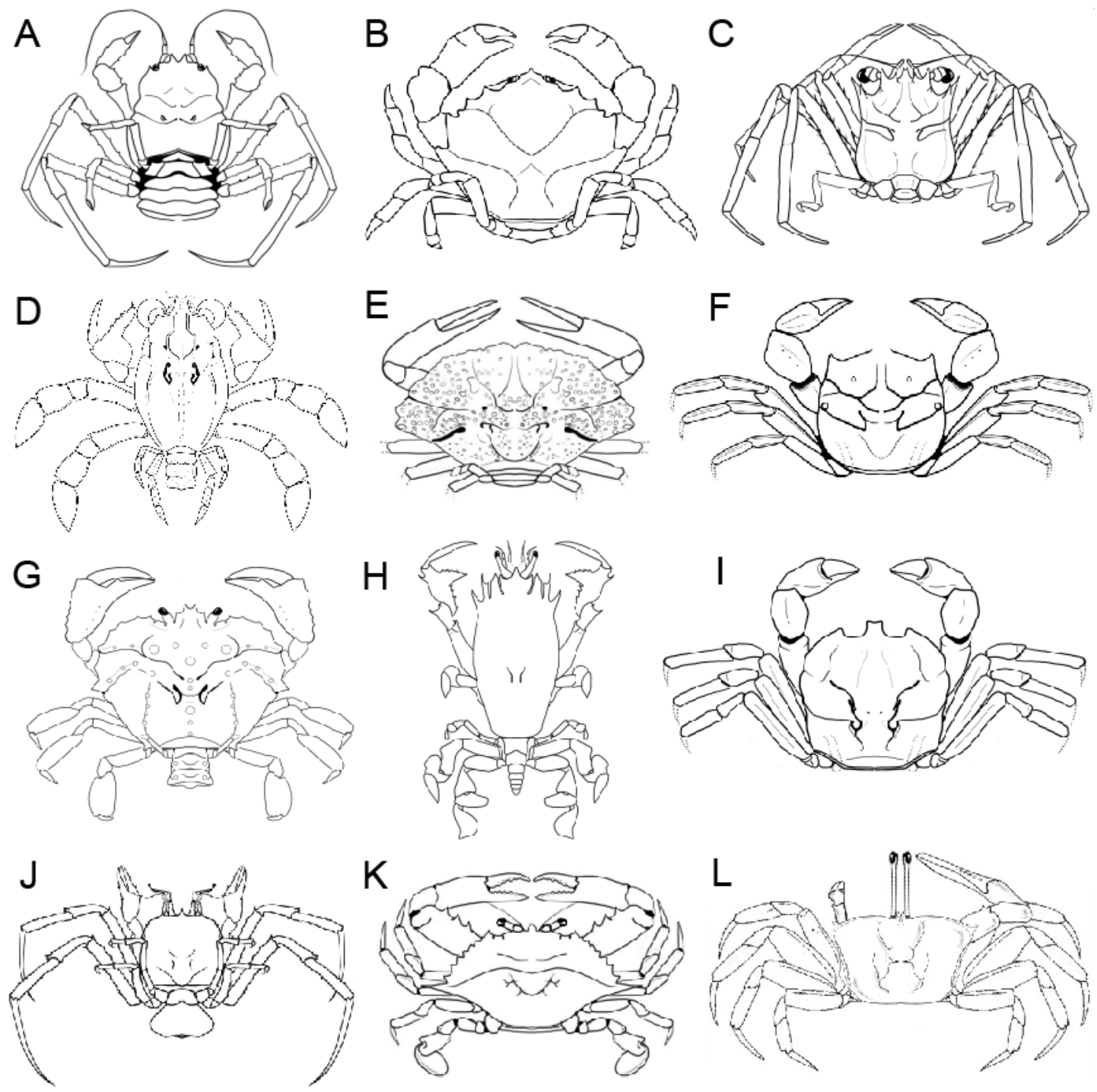

80 Figure 1. Diversity of form across the main extant and fossil groups of true crabs. A, Homolodromioidea. B, Dromioidea. C, Homoloidea. D, †Callichimaeroidea. E, † Etyoidea. F, †Torynommoidea. G. Raninoida:

$\dagger$ Necrocarcinoidea. H, Raninoidea. I, $\dagger$ Dakoticancroidea. J. Cyclodorippoidea. K, Eubrachyura: Heterotremata. L, Eubrachyura: Thoracotremata. Dagger $(\dagger)$ indicates extinct groups (modified from Luque et al., 2019a). Illustrations and figure by J. Luque. Line drawings not to scale.

The other three eye types are of the superposition type, which are better-suited for vision in dim light condition, and differ from apposition eyes by the presence of a "clear zone" between the outer structures of the eye and the retina (Cronin and Porter, 2008) (Fig. 2B-C). Parabolic superposition eyes predominantly have hexagonal facet shapes in hexagonal packing, while the sides of the crystalline cones (the structure under each facet of the eye surface) are shaped in the form of a parabola and the ommatidia have a light guide that focuses the collimated light onto the retina 
(Fincham, 1980; Nilsson, 1989). Refracting superposition eyes (Fig. 2B) also have hexagonal facets in hexagonal packing, but their crystalline cones have a refractive index gradient that bends

95 incoming light to focus it on the retina (Nilsson et al., 1986; Nilsson, 1990). Finally, the reflecting superposition eyes (Fig. 2C) lack the refractive index gradient of the refracting superposition eye or the light guides of the parabolic superposition type, but instead focus an image by reflecting light off the sides of the crystalline cones as occurs in a four-sided mirror box, hence the common name “mirror eyes" (Vogt, 1975; Land, 1976). Unlike the facets of apposition, parabolic superposition, and

100 refracting superposition eyes, which share the presence of hexagonal to roundish facets packed in a hexagonal lattice, reflecting superposition eyes have distinctive square facets packed in an orthogonal lattice and are also square in cross-section (Fig. 5). Among crustaceans, mirror eyes are unique to decapods, and are the only eye type with rectangular, square facets.

Interestingly, while most crustaceans groups with compound eyes show only the apposition 105 type through larval and adult stages, crabs alone have representatives of all four eye types (Porter and Cronin, 2009) (Fig. 5). The evolutionary history of apposition and superposition eyes is still poorly understood (Nilsson, 1983; Gaten, 1998). In particular, little is known about the genetic and developmental mechanisms regulating the expression of a particular eye type in the post-larva, and the information provided by the fossil record has been sparse and fragmentary, until now.

A

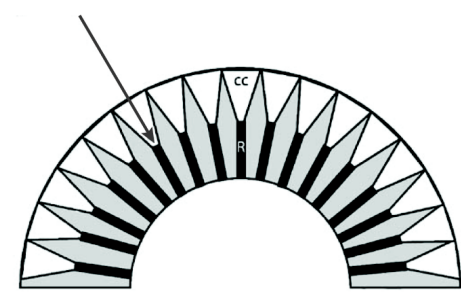

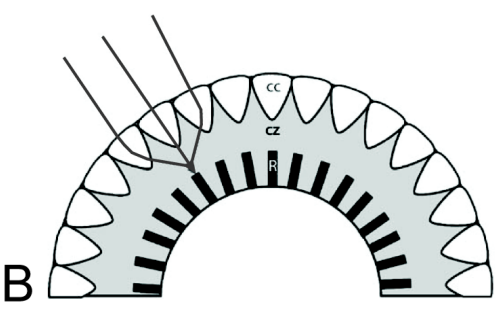

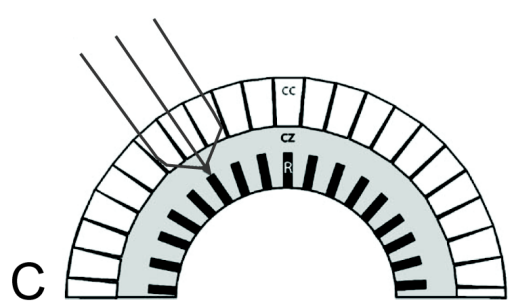

Figure 2. Types of compound eyes in brachyuran crabs. A: Apposition eye- works well in relatively bright light. A single light beam is focused on the retina of a single ommatidium (thin line). B-C: superposition eyes are better suited for vision in dim light. Recognized by the presence of a "clear zone" (grey area) between the outer lenses (white) and the retina (black). B: Refracting superposition eye- the crystalline cones contain a refractive index gradient that bends incoming light to focus it on the retina (thin lines); multiple light rays may fall on a single ommatidial retina. C: Reflecting superposition eye- light rays are focused by reflections off the sides of the cones, which are square instead of round in cross section, and are typical of 'mirror' optics; here too, multiple

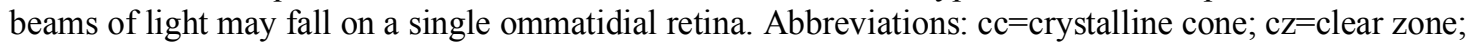
$\mathrm{r}=$ rhabdom. Drawings modified from Cronin and Porter (2008). Parabolic superposition not illustrated. 
bioRxiv preprint doi: https://doi.org/10.1101/786087; this version posted October 7, 2019. The copyright holder for this preprint (which was not certified by peer review) is the author/funder, who has granted bioRxiv a license to display the preprint in perpetuity. It is made available under aCC-BY-NC-ND 4.0 International license.

Page -6-

Podotremata $=$ male $\&$ female coxal

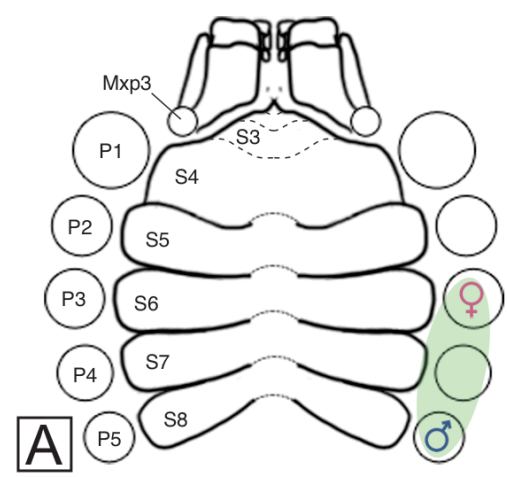

Heterotremata $=$ male coxal, female thoracic (sternal)

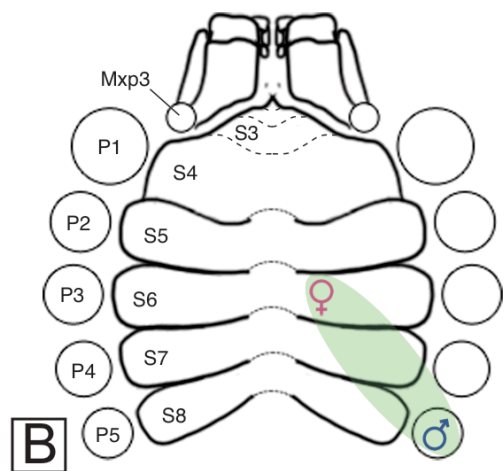

Thoracotremata $=$ male $\&$ female thoracic $($ sternal)

Figure 3. Schematic diagram showing the position of sexual openings in brachyuran crabs. A, podotreme condition; B, heterotreme condition; C, thoracotreme condition. For all decapods, including Anomura and Brachyura, the plesiomorphic condition is males and females with coxal sexual openings, or podotreme. The innovation of sternal sexual openings in female crabs is presumed to have occurred once in the most recent common ancestor for heterotreme and thoracotreme crabs (=Eubrachyura). Illustrations and figure by J. Luque.

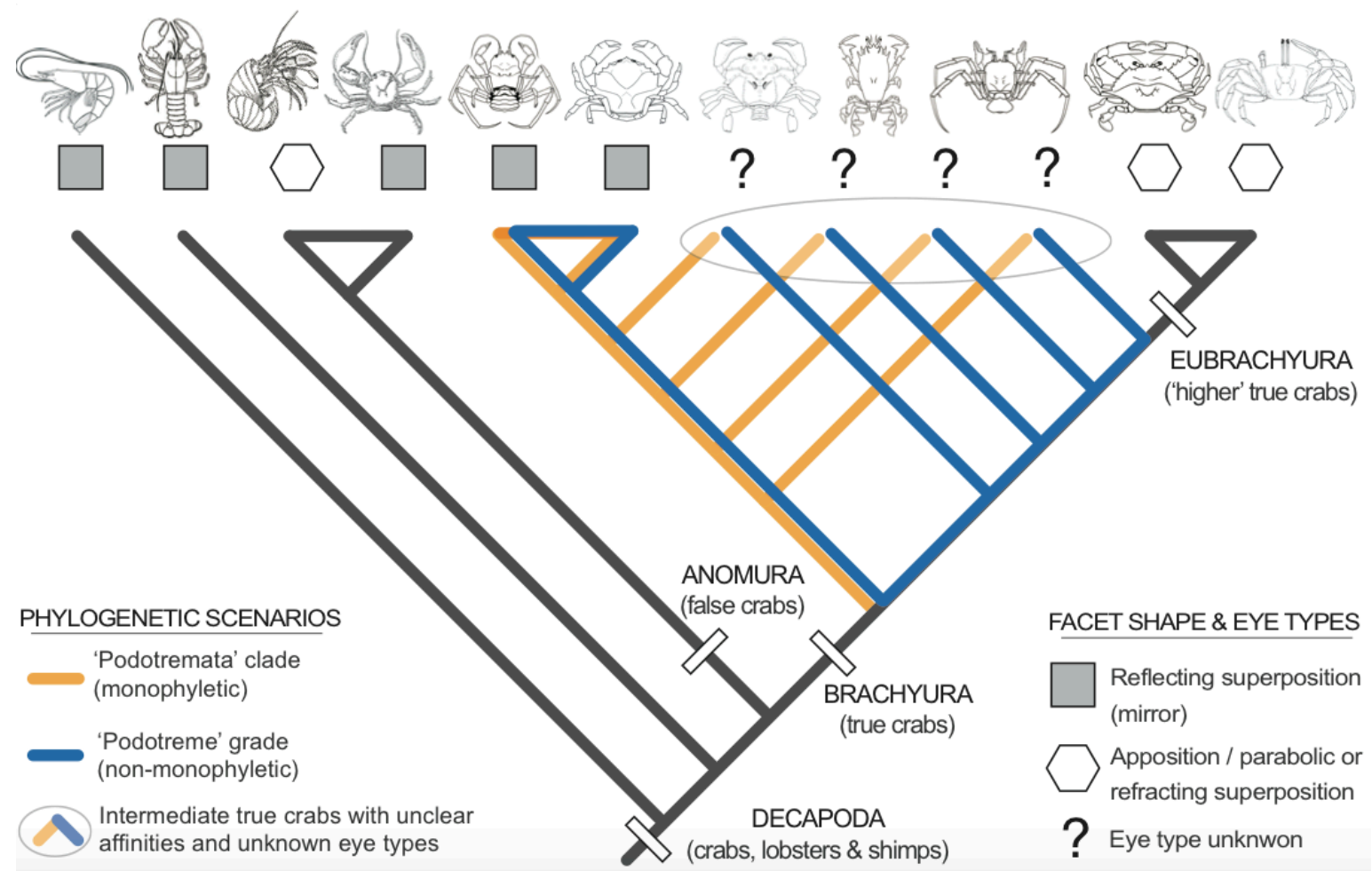

125 Figure 4. Schematic phylogenetic scenarios for the evolution of true crabs (Brachyura), and the distribution of their facet shape, packing, and visual systems. The main competing hypotheses suggest that either 'lower' true crabs, or podotremes, form a monophyletic clade Podotremata (orange lines), whereas podotreme crabs may represent a paraphyletic grade of increasing complexity (blue lines) with some intermediate groups closer to eubrachyurans than to other podotremes. 'Lower' brachyurans share reflecting superposition 'mirror' eyes (grey squares), while the 'higher'

130 brachyurans lack mirror eyes altogether and have either apposition, parabolic superposition, or refracting superposition eyes (white hexagons). In this work, we investigate the visual systems in intermediate 'lower' podotremes (white oval, and marked with '?'), to assess the utility of ommatidia morphology in resolving crab phylogeny. Figure by J. Luque. 


\section{Eye types in larval and post-larval crabs}

Most larval and adult crustaceans, including crabs, have compound eyes of the apposition type

135 (Gaten, 1998) (Fig. 5), suggesting that this eye type is the ancestral condition for crustaceans. However, among crustaceans, reflecting superposition or 'mirror' eyes are unique to post-larval Decapoda (Land, 2000). They are present in most extant penaeoid and caridean shrimp, lobsters, anomurans such as Galetheoidea (squat lobsters) and some pylochelideans (symmetrical hermit crabs), and the podotreme brachyurans Dromioidea, Homolodromioidea and Homoloidea (Gaten,

140 1998; Porter and Cronin, 2009; Scholtz and McLay, 2009). As such, the absence of mirror eyes in several derived crab groups is intriguing. In Eubrachyura or 'higher' crabs, the loss of reflecting superposition optics via secondary retention of larval apposition eyes appears to have occurred in their most recent common ancestor by progenetic paedomorphosis (Gaten, 1998).

Based solely on the position of sexual openings, taxonomists have traditionally grouped true

145 crabs into Podotremata, Heterotremata, and Thoracotremata (Guinot, 1977) (Fig. 2). This taxonomic grouping presumes that a) Heterotremata and Thoracotremata are monophyletic (together forming the section Eubrachyura), and b) Podotremata, or the 'lower' Brachyura, are monophyletic and form the sister group to Eubrachyura. However, the podotreme condition of coxal sexual openings is plesiomorphic and shared with all anomurans, other decapods, and even heterotreme brachyuran

150 males, casting doubts on its utility for classifying crab taxa (Luque et al., 2019a and references therein). Moreover, most studies dealing with phylogenetic analyses have recovered a paraphyletic podotreme grade (e.g., Ahyong et al., 2007; Scholtz and McLay, 2009; Karasawa et al., 2011; Tsang et al., 2014; Luque et al., 2019a; Wolfe et al., 2019). In addition, the distribution of visual systems across brachyuran clades is poorly understood. Early branches of crown podotremes like

155 Homoloidea, Dromiodea, and Homoloidea have 'mirror' eyes — which are plesiomorphic for crown Decapoda — while adult eubrachyurans have reverted to larval apposition eyes (Gaten, 1998). Therefore, the most derived group of crabs exhibits the most plesiomorphic eye morphology. Yet, almost nothing is known about the eye types present in 'intermediate' podotreme groups, either fossil or extant (Fig. 4), which has motivated the present study.

160 As Gaten (1998) suggested, if the stratigraphic ranges of the fossil and extant decapod crustacean groups can be combined with information about their eye types, then some phylogenetic patterns may appear. Here, we present a comprehensive review on the visual systems of true crabs, and integrate novel data on the external eye features of fossil and extant brachyurans. As very little is 
bioRxiv preprint doi: https://doi.org/10.1101/786087; this version posted October 7, 2019. The copyright holder for this preprint (which was not certified by peer review) is the author/funder, who has granted bioRxiv a license to display the preprint in perpetuity. It is made available under aCC-BY-NC-ND 4.0 International license.

Page -8-

known about the eyes in fossil and living 'intermediate' crabs, we explore the extents and limitations 165 of using eye form as an additional tool to understand crab evolution, while providing an overview of the ecology and development of crab visual systems, and their phylogenetic implications.

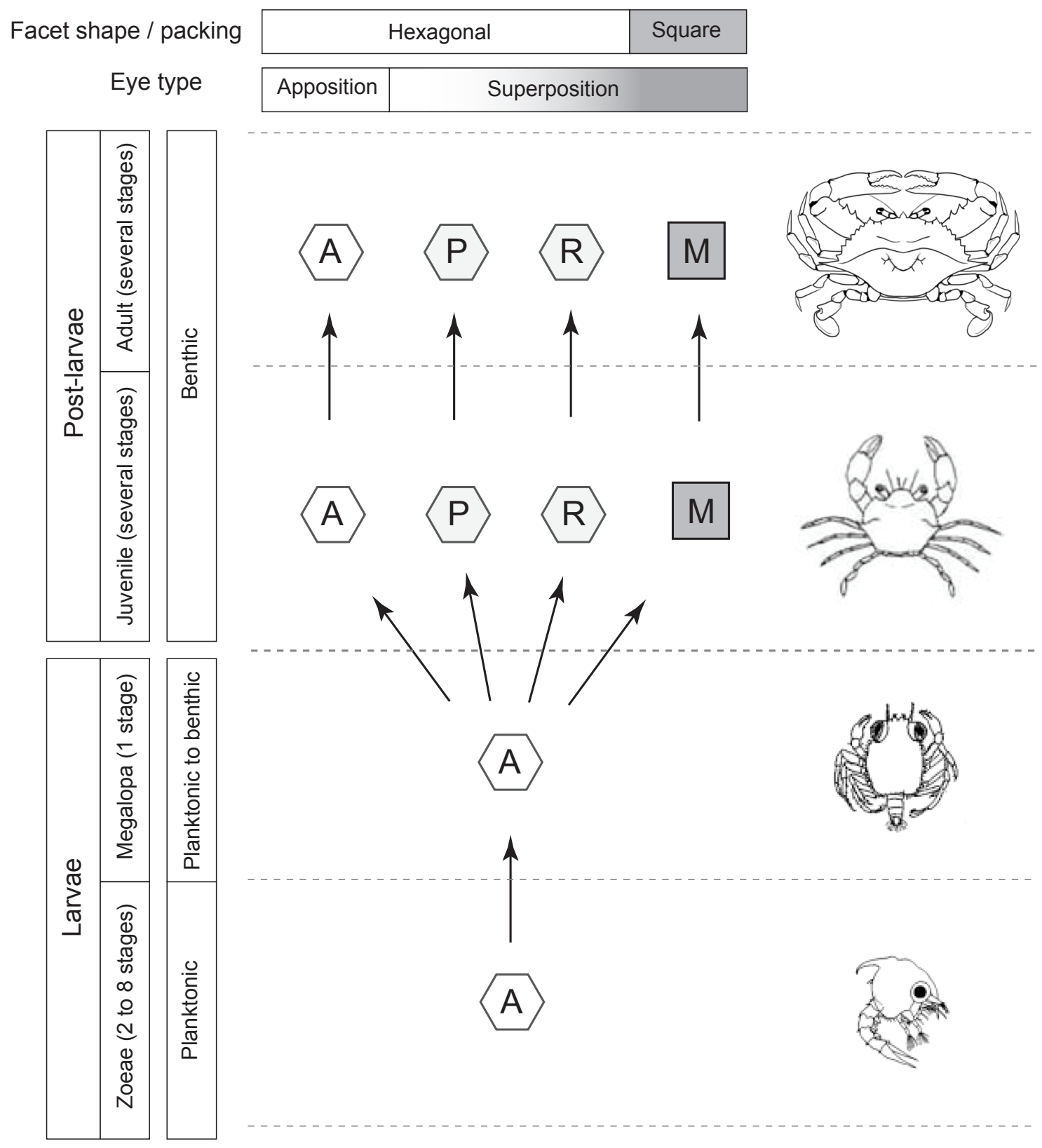

Figure 5. Distribution of eye types in crabs across life stages. The larval stages of brachyurans and other decapod crustaceans have apposition eyes, which is the ancestral state for malacostracans. In post-larval stages, the larval apposition eyes may either remain functional as apposition eyes, or undergo internal and external restructuration to function as superposition eyes. Externally, apposition (A), parabolic superposition (P), and refracting superposition (R) eyes share the hexagonal packing of hexagonal to round facets, while eyes of the reflecting superposition type (M) are modified to work as a mirror box, and have square facets with orthogonal packing. Figure by J. Luque. 


\section{MATERIALS AND METHODS}

\section{Institutional abbreviations}

AMNH: American Museum of Natural History, New York, USA.

IGM p: Colecciones Paleontológicas Museo José Royo y Gómez, Servicio Geológico Colombiano, Bogotá D.C., Colombia.

MNHN: Muséum national d'Histoire naturelle, Paris, France.

180 MUN-STRI: Mapuka Museum of Universidad del Norte, Barranquilla, Colombia.

NPL: Non-vertebrate Paleontology Lab, Jackson School Museum of Earth History, University of Texas, USA.

QMW: Queensland Museum, Brisbane, Australia.

USNM: United States National Museum of Natural History, Smithsonian Institution, Washington, D.C., USA.

YPM: Invertebrate Zoology Collections, Yale Peabody Museum, Yale University, New Haven, Connecticut, USA.

\section{Materials}

\section{Extant taxa}

Nineteen extant species across all podotreme superfamilies were studied from the invertebrate zoology collections of the USNM, MNHN, and QMW. Specimens were preserved in 70\% EtOH, and one eye from selected adult specimens was removed for microscope imaging and preserved in $70 \%$ EtOH. Illustrated taxa included Dicranodromia felderi Martin, 1990 (Homolodromioidea:

195 Homolodromiidae) (Fig. 6A-C); Dromia personata (Linnaeus, 1758) (Fig. 6E-F) and Hypoconcha sp. (Fig. 6G-I) (Dromioidea: Dromiidae), Dynomene filhol Bouvier, 1894 (Dromioidea: Dynomenidae) (Fig. J-L); Homola minima Guinot and Richer de Forges, 1995 (Fig. 7A-C), and Latreillopsis bispinosa Henderson, 1888 (Fig. 7D-G) (Homoloidea: Homolidae), Eplumula phalangium (De Haan, 1839) (Homoloidea: Latreillidae) (Fig. 7H-J);

200 Lysirude nitidus (A. Milne-Edwards, 1880) (=Lyreidus bairdii) (Fig. 8A-C) and Lysirude griffini Goeke, 1985 (Fig. 8D-F) (Raninoidea: Lyreididae), Cyrtorhina granulosa Monod, 1956 (Fig. 8G-I), Symethis sp. (Fig. J-L), Cosmonotus grayi White, 1848 (Fig. 9A-C), Notopus dorsipes (Linnaeus, 1758) (Fig. 9D-F), Ranilia muricata H Milne Edwards, 1837 (Fig. 9G-I), Ranina 
ranina (Linnaeus, 1758) (Fig. J-L), Notopoides latus Henderson, 1888 (Fig. 10A-C), Notosceles

205 viaderi Ward, 1942 (Fig. 10D-F), Raninoides benedicti Rathbun, 1935b (Raninoidea: Raninidae)

(Fig. 10G-I); and Clythrocerus nitidus (A. Milne-Edwards, 1880) (Cyclodorippoidea:

Cyclodorippidae) (Fig. 10J-L). A complete list of the extant material studied and associated information is provided in Table 1.

210 Fossil taxa

We investigated the ommatidia morphology in eight fossil species of podotreme (five species) and eubrachyuran (three species) crabs with eyes preserved. Studied taxa included $\uparrow$ Callichimaera perplexa Luque et al., 2019a (†Callichimaeroidea: $\uparrow$ Callichimaeridae), from the upper Cenomanian-lower Turonian Churuvita Group (95-90 Mya) of Boyacá, Colombia (Fig.

215 11); $\uparrow$ Xanthosia sp. (†Etyoidea: $\dagger$ Etyidae), from the upper Albian Pawpaw Formation of Texas, USA (Fig. 12A-F), and $\uparrow$ Caloxanthus americanus Rathbun, 1935a ( $\dagger$ Etyoidea: $\uparrow$ Feldmannidae), from the Cenomanian Grayson Formation of Texas (Fig. 12G-I); †Cenomanocarcinus spp. ( $\uparrow$ Necrocarcinoidea: $\uparrow$ Cenomanocarcinidae), from the lower-mid Turonian San Rafael Formation and the upper Coniacian Conejo Formation of Boyacá, Colombia (Fig. 13); †Avitelmessus

220 grapsoideus Rathbun, 1935a (†Dakoticancroidea: $\dagger$ Dakoticancridae), from the Maastrichtian Ripley Formation of Mississippi and the Peedee Formation of North Carolina, USA (Fig. 14); two species of fossil Eubrachyura, from lower-mid Santonian Conejo Formation and the Campanian of Boyacá, Colombia (Fig. 15A-F); and a fossil freshwater crab from the lower Miocene Pedro Miguel Formation of the Panama Canal expansion zone, Panama (Fig. 15G-I). A 225 complete list of the fossils studied and their associated information is provided in Table $\mathbf{1}$.

\section{Methods}

\section{Tissue processing}

Eyes of selected extant adult crabs from museum collections, preserved in $70 \% \mathrm{EtOH}$ were

230 dissected and prepared for Scanning Electron Microscope (SEM) via dehydration through a series of rinses in $\mathrm{EtOH}$ at $70 \%, 90 \%$, and twice at 100\% at intervals of 20 and 30 minutes for small and large samples, respectively. Then the tissues were rinsed for similar time intervals in a 
mixture of EtOH and Hexamethyldisilazane (HMDS) at 25:75, 50:50, and 75:25 ratios, plus two final rinses in 100\% HDMS. This tissue dehydration technique is faster, easier, and less

235 expensive than the critical point drying with $\mathrm{CO} 2$.

\section{Imaging}

Most fossils were coated with sublimated $\mathrm{NH}_{4} \mathrm{Cl}$ prior to photographing whole specimens to enhance relief and fine ornament. Sets of photographs at different focal points were taken with a

240 Nikon Eclipse 80i + Nikon Digital Camera Dxm 1200f, Olympus SZX16® Research Stereomicroscope with a digital camera Qimaging Retiga 2000R Fast 1394, and a Leica Macroscope with Spotflex digital camera. The resulting multi-layered stacks of photos were merged in a single high-definition image using the stacking software Helicon Focus stacking software. Extant specimens were photographed with a Nikon Digital Camera D3100 with

245 MicroNikkor $60 \mathrm{~mm}$ and $105 \mathrm{~mm}$ lenses.

Dissected and mounted eyes from fossil and extant crabs were studied under Zeiss Scanning Electron Microscope (SEM) Evo 40vp under low vacuum and variable pressure and Back-scattered Electron Detector (BSED) with acceleration voltages of 15 and $20 \mathrm{kV}$, and under a Zeiss Sigma 300 VP-FESEM scanning electron microscope at the Smithsonian Tropical Research

250 Institute, Panama (STRI), and the University of Alberta, Edmonton, Canada. All eye samples from extant taxa were coated with $\mathrm{Au} / \mathrm{Pd}$ prior to SEM imaging, except from two specimens imaged using an Olympus FV1000 Confocal Microscope.

\section{Lens packing and facet measurements}

255 A strongly supported phylogenetic framework is missing for podotremes (Fig. 16), and is the subject of the present investigation, therefore to assess the sources of variation in lens shape and packing among brachyuran crabs, we utilized geometric morphometrics (Bookstein, 1991). Simple measurements of cornea dimensions and facet diameters (Table 1) were obtained using ImageJ. For morphometric measurements, we examined seventeen museum specimens

260 representative of sixteen genera, all representing adult individuals (Table 1). For each specimen, we determined whether square or hexagonal facets were present. Lens packing was represented by four two-dimensional landmarks taken at the centroid of four adjacent lenses (Fig. 17A,B). 
From each individual, we collected five sets of landmarks from different areas of the eye, except in cases where the curvature of the eye or damage to the ommatidia severely affected landmark

265 acquisition. All landmark measurements were taken from high magnification images (Figs 6-15), and measured using the software TpsDig (Rohlf, 2005), which translates landmarks into Cartesian coordinates. Those Cartesian coordinates, as transformed landmarks, underwent Procrustes superimposition in PAST (Hammer et al., 2001) to remove the effects of rotation, translation, and size, which minimizes the shape difference between sets of landmarks

270 (Bookstein, 1991). This procedure translates all specimens to the origin, scales them, and rotates them to minimize deviations of landmark coordinates to an average configuration for all specimens. Procrustes superimposition also transforms the Cartesian coordinates originally taken during landmark acquisition into Procrustes coordinates (i.e., this creates a covariance matrix of Procrustes residuals). Because of this, axes are scaled in Procrustes units which are arbitrary units

275 that only serve as a within-study metric. Principal components (PCs) were calculated from the covariance matrix of the Procrustes coordinates (Dryden and Mardia, 1998), and that principal components space is often referred to as a 'morphospace' (Fig 17C). Each data point in that morphospace corresponds to a particular shape configuration. The closer two data points are, the more similar they are in shape. In a principle components analysis of landmark data, each PC

280 describes a different component of shape, and PC axes are uncorrelated.

To assess the relationship between facet shape and packing by geometric morphometrics (as outlined above), we performed a multivariate analysis of variance (MANOVA) from PC scores in PAST (Hammer et al., 2001). Facet shape was treated as a categorical variable (i.e., hexagonal vs. square).

\section{RESULTS}

Below, we describe the gross, facet, and packing morphology recorded for the eyes of fossil and extant species of podotreme crabs here investigated. 


\section{Eyes of extant podotreme brachyurans}

\section{Homolodromioidea}

Dicranodromia felderi has globular eyes slightly larger than the eyestalk. The podophthalmite is partly covered dorsally in small fine to conical spines, and the eye and eyestalk partially fit a

295 shallow orbit laterally bounded by a short, triangular, anterolaterally diverging outer orbital spine (Fig. 6A). In the studied specimen, the corneal eye is nearly as wide as long, its width is approximately $6 \%$ the carapace, and is covered in small ommatidia ( $35 \mu \mathrm{m}$ in diameter) with square facets packed in a rectilinear lattice (Fig. 6B,C; Table 1).

\section{$300 \quad$ Dromioidea}

The dromiids Dromia personata (Fig. 6E,F), Hypoconcha sp. (Fig. 6G-I), and the dynomenid Dynomene filholi (Fig. 6J-L) all have eyes with square facets in an orthogonal array. In Dromia personata, the eye is small, globular, and about as long as the eyestalk. The podophthalmite is covered with plumose setae, where secondary acicular setae stem from the primary setae (Fig.

305 6E). Its corneal surface is nearly as wide as long, with a width diameter less than $6 \%$ the carapace length, and is covered in small square ommatidia (35 $\mu \mathrm{m}$ diameter) (Fig. 6F; Table 1). In Hypoconcha sp., the eyes are also globular, wider than long, and slightly longer than the eyestalk. The cornea has a diameter that is about $9 \%$ of the carapace length, and is covered with small rhomboid ommatidia (40 $\mu \mathrm{m})$ (Fig. 6H,I). In Dynomene filholi, the eyes are small and globular,

310 and shorter than the eyestalk, and like in Dromia, the podophthalmite is covered with plumose setae (Fig. 6K). The cornea has a diameter about $8 \%$ the carapace length, and it is covered with small square ommatidia (40 $\mu \mathrm{m}$ in diameter) with depressed edges (Fig. 6L).

Square facets packed in an orthogonal lattice have been previously reported for other dromiids and dynomenids such as Dromia vulgaris and Dynomene pilumnoides (Gaten, 1998;

315 Scholtz and McLay, 2009; D. Guinot, pers. comm. to JL, 2016), supporting the distribution of these features across genera of Homolodromioidea and Dromioidea crabs. 


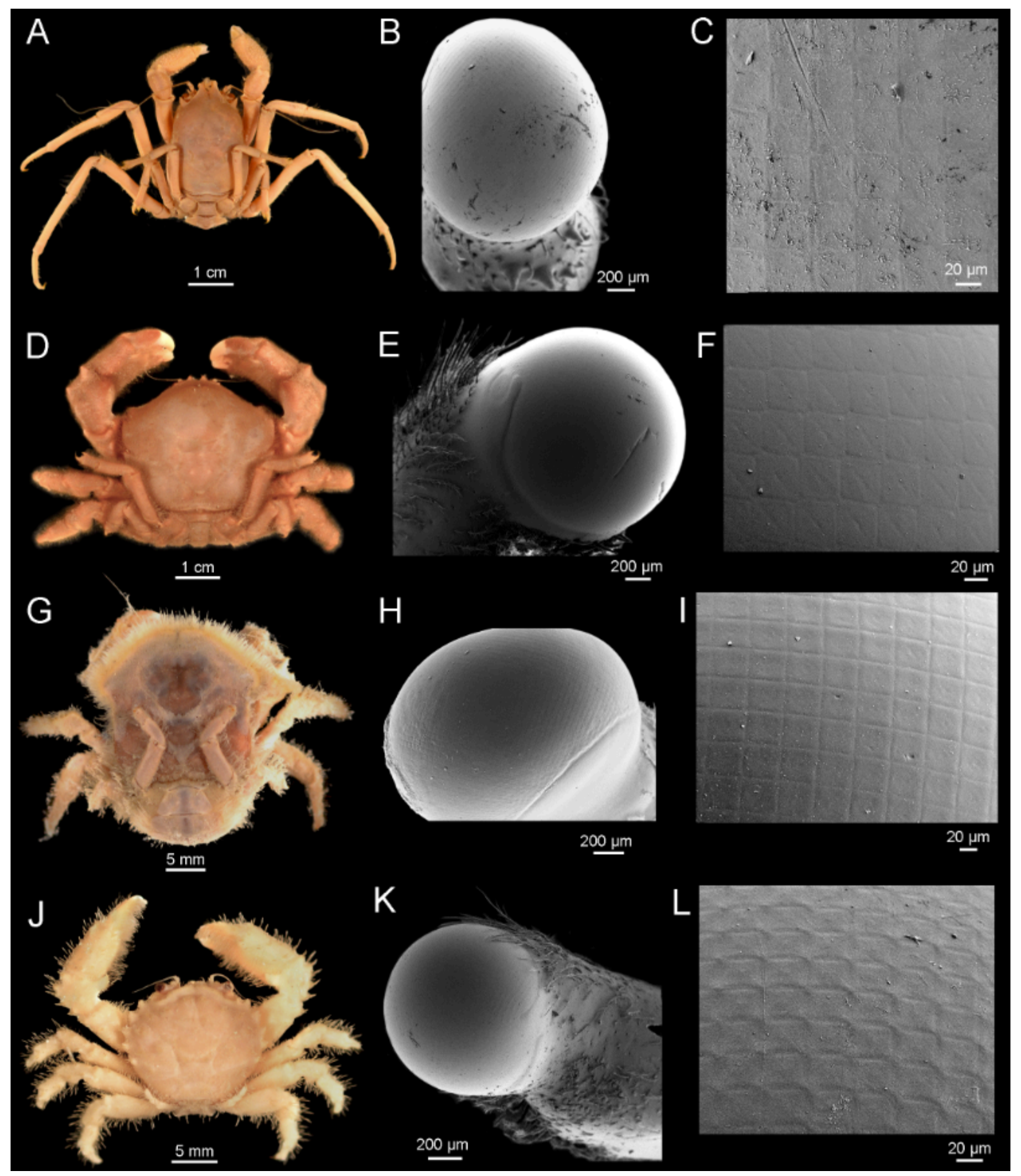

Figure 6. Homolodromioidea and Dromioidea. A-C, Homolodromioidea: Homolodromiidae: Dicranodromia felderi, USNM 252207; A, dorsal view of female; B, SEM image of right eye; C, details of the cornea bearing square facets in orthogonal packing. D-I, Dromioidea: Dromiidae; D, ?Moreiradromia sarraburei, USNM 1277453, dorsal view of male; E-F, Dromia personata, USNM 1277452, female; F, SEM image of right eye; F, details of the cornea bearing square facets in orthogonal packing; G-I, Hypoconcha sp., 186466; G, dorsal view of male; H, SEM image of right eye; I, details of the cornea bearing square facets in orthogonal packing. J-L, Dromioidea: Dynomenidae: Dynomene filholi, USNM 121402; J, dorsal view of male; K, SEM image of right eye; L, details of the cornea bearing square facets in orthogonal packing. Figure by J. Luque. 

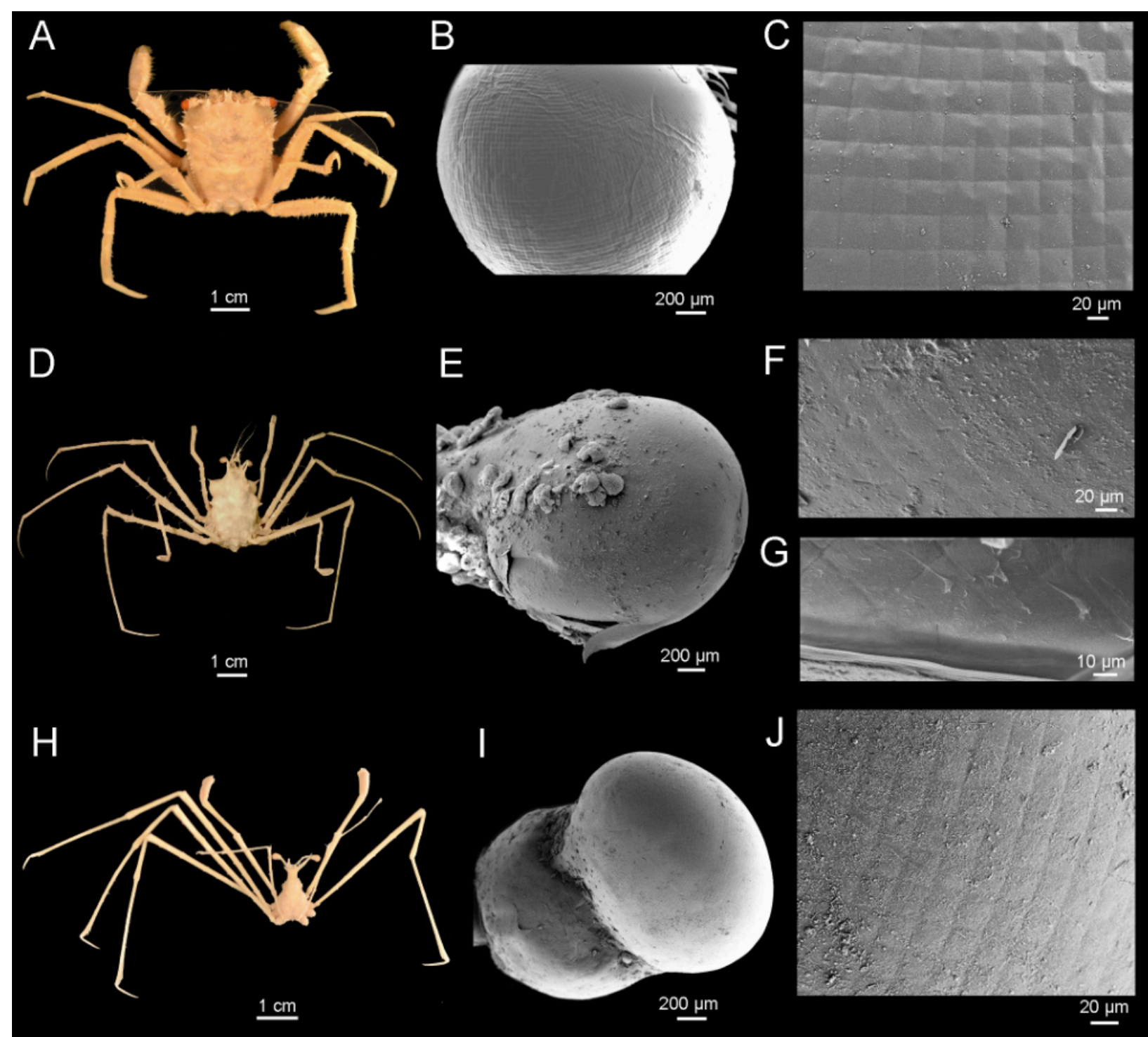

Figure 7. Homoloidea. A-G, Homolidae; A-C, Homola minima, USNM 1185786; A, dorsal view of male; B, SEM image of globular right eye; $\mathrm{C}$, details of the cornea bearing square facets in orthogonal packing. D-F, Latreillopsis bispinosa, QMW.17070; D, dorsal view; E, SEM image of right eye; F, details of the cornea bearing square facets in orthogonal packing; G, detail of the eye under the cuticle, showing square facets in orthogonal packing. $\mathrm{H}-\mathrm{I}$, Latreillidae: Eplumula phalangium, USNM 74587; H, dorsal view of male; I, SEM image of right eye and podophthalmite; J, details of the cornea bearing square facets in orthogonal packing. Figure by J. Luque.

\section{$\underline{\text { Homoloidea }}$}

340 The homolid crab Homola minima has hemispherical globular eyes that rest on a cylindrical podophthalmite that is slightly longer than the corneal eye. The basophthalmite is slender, cylindrical, and more than twice as long as the corneal eye or the podophthalmite (Fig. 7A). As in other homolids, the podophthalmite rests on a depressed space acting as a false orbit (Davie et al., 
2015). In the studied specimen, the corneal eye is nearly as wide as long, its width is

345 approximately $7 \%$ the carapace length, and is covered with small square ommatidia (approx. 30 $\mu \mathrm{m}$ in diameter) packed in an orthogonal lattice (Fig. 7B,C; Table 1). Similarly, the homolid Latreillopsis bispinosa has a large globular eye with a short podophthalmite and a slender and much longer basophthalmite (Fig. 7D). The cornea is smooth, nearly as wide as long, its width is less than $8 \%$ the carapace length, and is covered in small square ommatidia ( $35 \mu \mathrm{m})$ packed in an

350 orthogonal lattice (Fig. 7F; Table 1). The boundaries between facets are less conspicuous than in the eye of Homola minima, but the overall facet shape and array is still evident above and below the cuticle (Fig. 7F,G). The latreillid Eplumula phalangium has globular eyes, but they rest in shorter podophthalmites compared to the other homoloid species studied. The cornea is wider than it is long, about $13 \%$ as wide as the carapace maximum length, and is covered with small

355 square facets $(24.5 \mu \mathrm{m}$ in diameter $)$ in orthogonal array.

Similar facet shapes and packing match previous findings for other homoloid taxa such as Paromola cuvieri, for which eyes of the reflecting superposition (mirror) type have been reported (Gaten, 1998).

\section{$360 \quad$ Raninoidea}

The lyreidid crab Lyreidus nitidus (Fig. 8A) has small sub-conical eyes resting in stout and much longer podophthalmite, nearly 66\% larger than the corneal eye, and covered in fibrous setae (Fig. 8B). The eye and eyestalk are partially protected by a narrow orbit with one supraorbital fissure, and a produced, acute, triangular outer orbital spine directed anteromesially. The cornea width is

365 approximately $1.2 \%$ the length of the carapace, and it is constituted by a few hundred small hexagonal facets that are packed in hexagonal array, with an average facet diameter of $23 \mu \mathrm{m}$ (Fig. 8C; Table 1). The studied specimen of Lysirude griffini (Fig. 8D) has even more reduced sub-conical eyes and a longer and broader podophthalmite than L. nitidus; the podophthalmite is nearly twice as long as the corneal eye, and it is partly covered in small setae (Fig. 8E). Both eye

370 and eyestalk are barely protected by a narrow orbit with one supraorbital fissure, and a short, blunt, triangular outer orbital spine directed anteriorly (Fig 8D). The cornea width is approximately $1.5 \%$ the length of the carapace, and it is constituted by a few hundred small hexagonal facets that are packed in hexagonal array, with an average facet diameter of $23 \mu \mathrm{m}$ 
(Fig. 8C; Table 1). Hexagonal facets in hexagonal array have been reported for Lyreidus

375 tridentatus (see Scholtz and McLay, 2009), suggesting a shared lack of 'mirror' eyes among crabs of the family Lyreididae.

Among all the podotreme crabs studied, those of the family Raninidae have the broadest range of eye shapes, sizes, and orbital constructions. In the subfamily Cyrtorhininae, Cyrtorhina granulosa (Fig. 8G) shows a considerable reduction of the corneal region compared with the rest

380 of the eyestalk. Its cornea is sub-conical and dorsally truncated by an extension of the cuticle of the podophthalmite that extends towards the pole of the eye, further reducing the area occupied by the cornea (Fig. 8H). The cornea width is approximately $1.8 \%$ the length of the carapace, and it is constituted by small hexagonal facets in hexagonal array, with an average facet diameter of $35 \mu \mathrm{m}$ (Fig. 8H, I; Table 1). The facets across the cornea are similar in size. The cuticular lenses

385 in C. granulosa include a thin epicuticle forming the slightly convex outer facets, an underlying thin exocuticle with a concave center, and a membranous underlying endocuticle forming concave facets with raised edges. The podophthalmite is three times larger than the cornea. It is covered in microcuticular tuberculations and bears multiple setal pits nucleated by a single reduced seta in each. The medial and proximal dorsal portions of the podophthalmite are

390 ornamented with several sub-conical to fungiform nodes ranging in size, the largest of which are capped by an eroded roundish top. Short orbits barely protect the eyes, with a sub-horizontal supraorbital margin bearing two fissures separating the short, blunt, triangular orbital spines.

Species of the subfamily Symethinae have the shortest eyes of all the raninoids studied. In Symethis sp. (Fig. 8J) the eyestalk is very reduced, and the corneal eye is concealed in a very 395 narrow orbit, considerably restricting the motion of the eye. The cornea maximum width is about $1.4 \%$ of carapace length. The facets across the cornea are quite different in shape and size; the most central facets are hexagonal in hexagonal packing (about $35 \mu \mathrm{m}$ ), while the peripheral facets towards the eyestalk are considerably smaller (around $14.5 \mu \mathrm{m}$ ) and with irregular shapes and packing (Fig. 8K, L; Table 1).

The genera in the subfamily Notopodinae all have well developed eyes on long eyestalks. In Cosmonotus grayi, the length of the podophthalmite seems to be the most extreme across raninoids, measuring half the length of the dorsal carapace (Fig. 9A). Its cornea is sub-cylindrical (Fig. 9B), longer than wide, approximately 5\% the length of the carapace, and it bears small flattened hexagonal facets around $20 \mu \mathrm{m}$ in diameter, with hexagonal packing, and with raised 
405 facet edges (Fig. 9C; Table 1). Notopus dorsipes (Fig. 9D) and Ranilia muricata (Fig. 9G) also have corneae that are longer than wide, sub-cylindrical, with a diameter about $3 \%$ the carapace length, and three times shorter than the eyestalk. Their facets are also hexagonal to roundish, well defined, and packed in a hexagonal array. The facet diameter in $N$. dorsipes is around $26.5 \mu \mathrm{m}$ (Fig. 9E,F), and $32 \mu \mathrm{m}$ in R. muricata (Fig. 9H,I; Table 1).

410 The subfamily Ranininae has only one living genus and species, Ranina ranina. It is the largest of all raninoids, reaching carapace length sizes over $15 \mathrm{~cm}$ (Luque, unpublished data). Ranina eyes are elongate, elliptical to sub-cylindrical (Fig. 9J,K). The eyestalk has a long podophthalmite twice as long as the cornea, and a long basophthalmite articulating at an angle. Its orbits are narrower than the eyes, but the long podophthalmite and basophthalmite articulate in

415 such a way that allows the eye to be retracted semi-vertically into the orbit. The cornea diameter is on average $5 \%$ the carapace length, and is made up of thousands of hexagonal facets packed hexagonally with an approximate diameter of $52 \mu \mathrm{m}$ (Fig. 9K,L; Table 1).

Finally, extant genera in the subfamily Raninoidinae share the presence of small elliptical eyes on longer eyestalks, all bearing hexagonal facets in hexagonal packing. All three taxa have

420 sub-horizontal orbits with two well-developed orbital fissures and orbital spines. In the studied specimen of Notopoides latus (Fig. 10A) the cornea width is 5\% the carapace length, and the facets diameter measure around $42 \mu \mathrm{m}$ (Fig. 10B,C), while in Notosceles viaderi (Fig. 10D) the cornea width is less than $3 \%$ the carapace length, and the facets measure around $38 \mu \mathrm{m}$ (Fig. 10E,F; Table 1). The eyestalks of Raninoides benedicti (Fig. 10G) are longer than in the other

425 Raninoidinae genera, approximately four times as long as the cornea. The cornea diameter is $2.5 \%$ the carapace length, and the facets measure $26 \mu \mathrm{m}$ in diameter (Fig. 10H,I; Table 1).

\section{Cyclodorippoidea}

The eyes of cyclodorippoids are little known. The specimen of Clythrocerus nitidus studied here

430 (Fig. 10J) has small, roundish eyes, with a cornea nearly as long as it is wide, and as long as the podophthalmite. The cornea diameter is about $11 \%$ of carapace length, and is covered in small, well-defined hexagonal facets in hexagonal array. Facet diameter is $35 \mu \mathrm{m}(\mathbf{F i g}$. 10K, L; Table 1). Previously, round facets in hexagonal packing have been reported for Krangalangia spinosa (see Scholtz and McLay, 2009), supporting the absence of mirror eyes in cyclodorippoid crabs. 

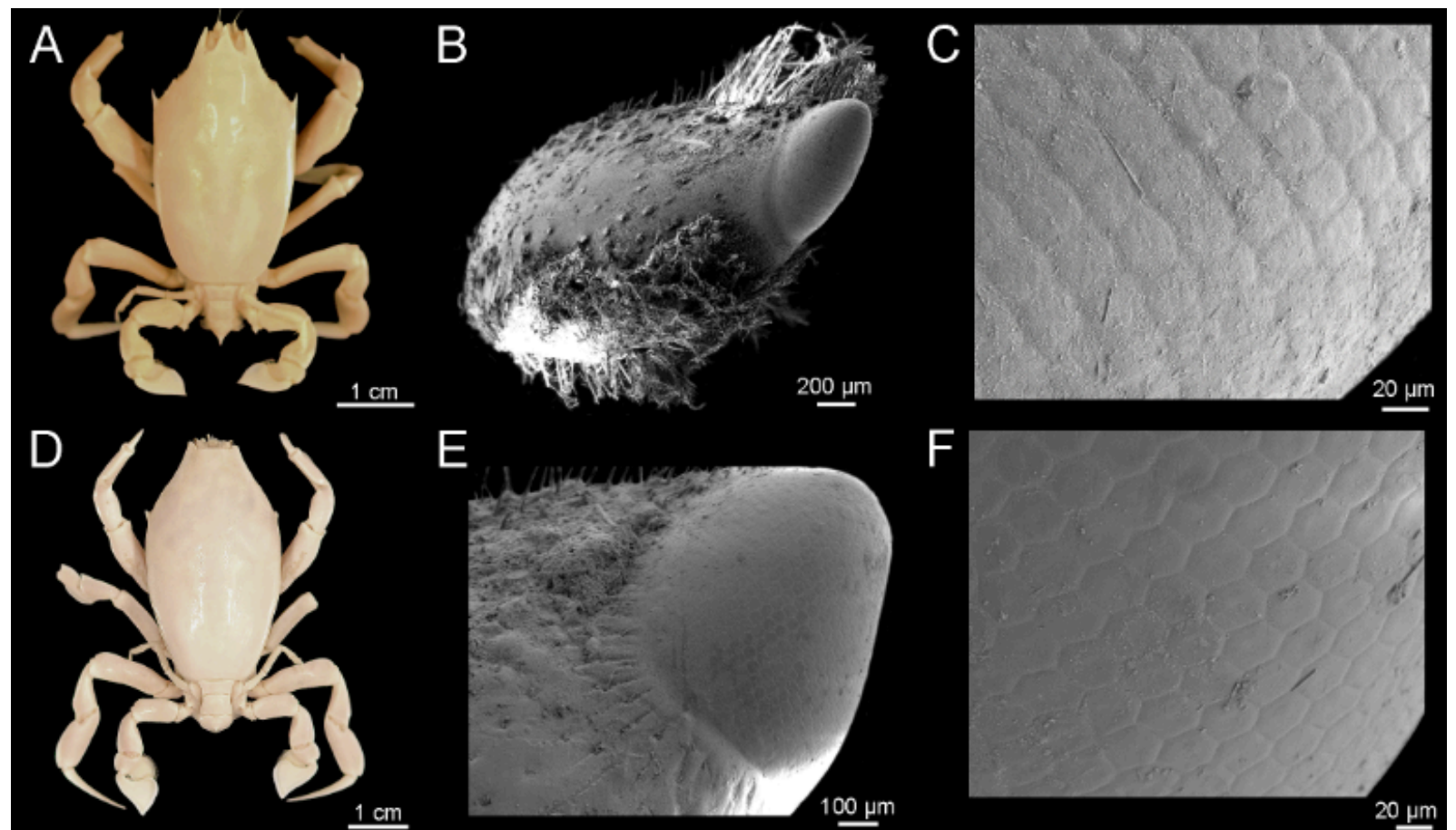

E
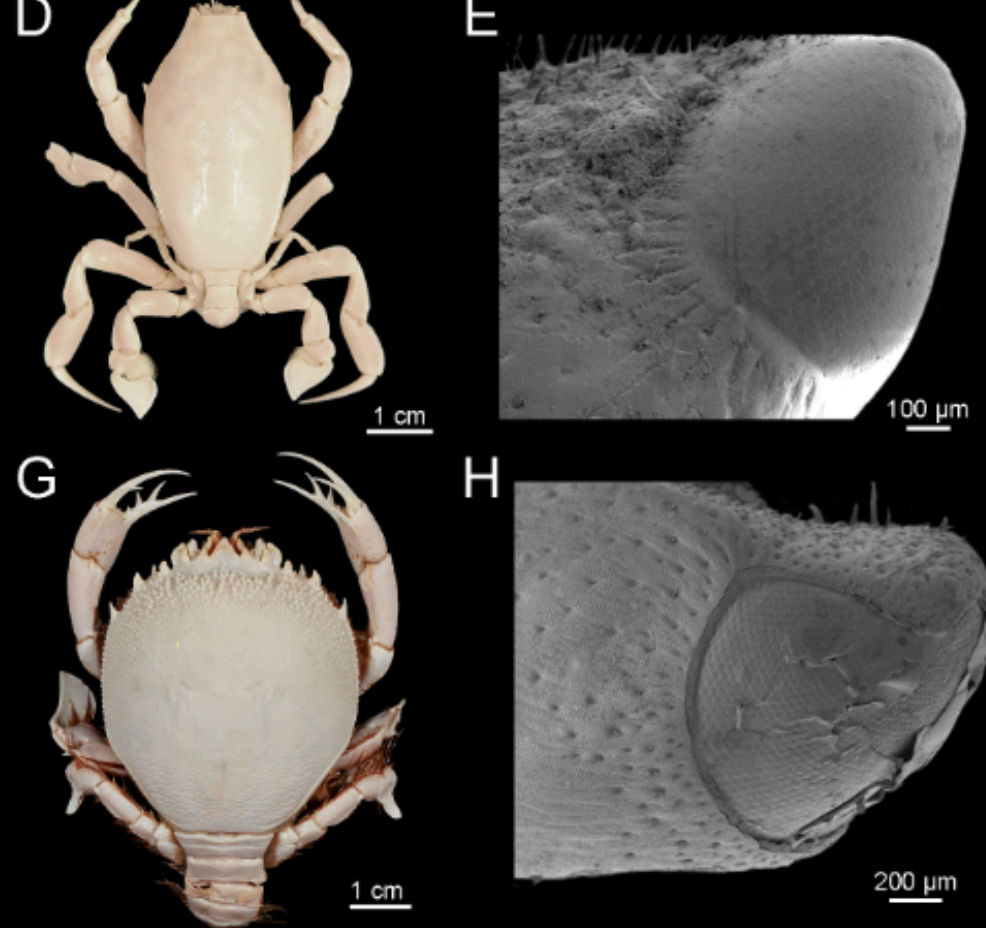

F
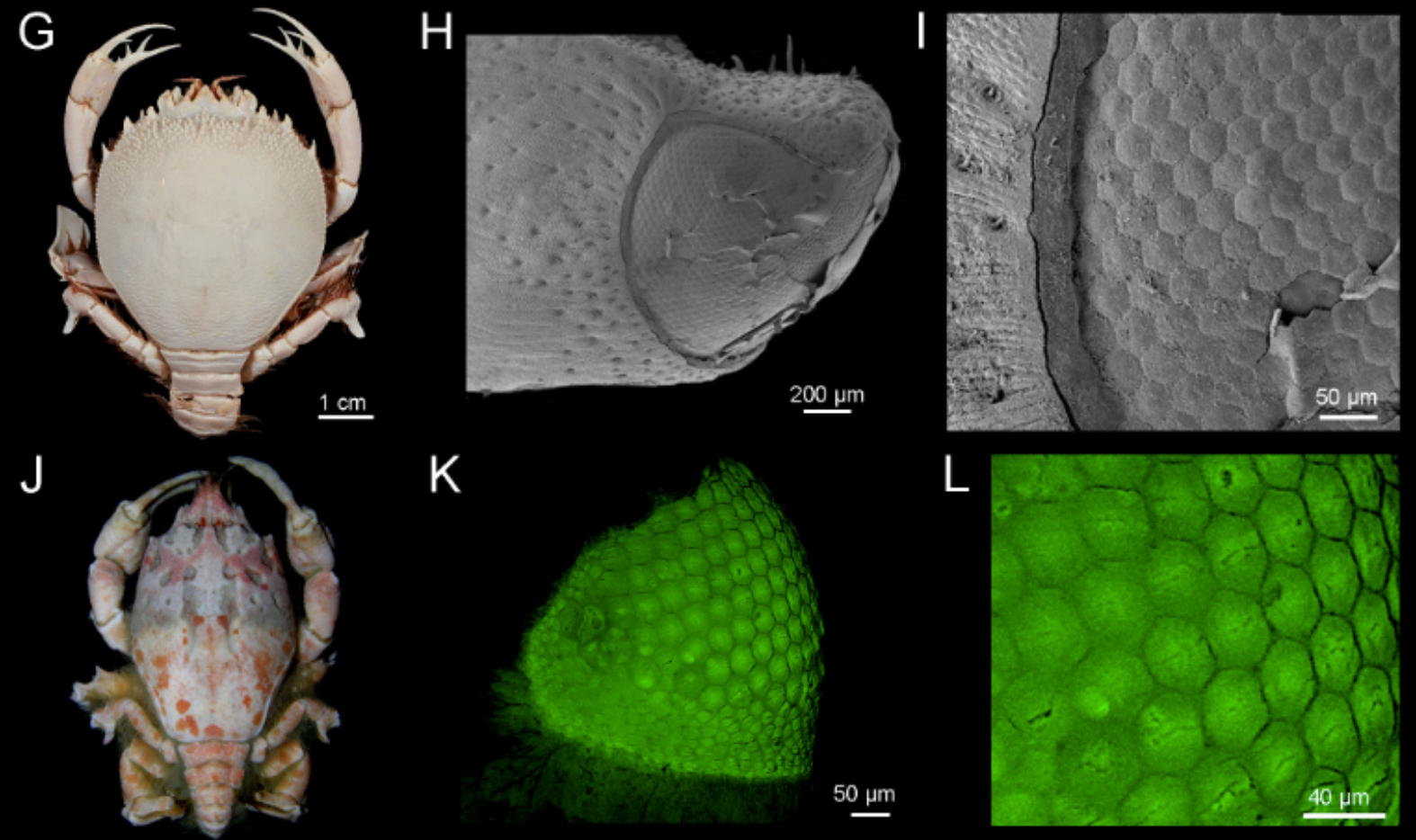

\section{$200 \mu \mathrm{m}$}
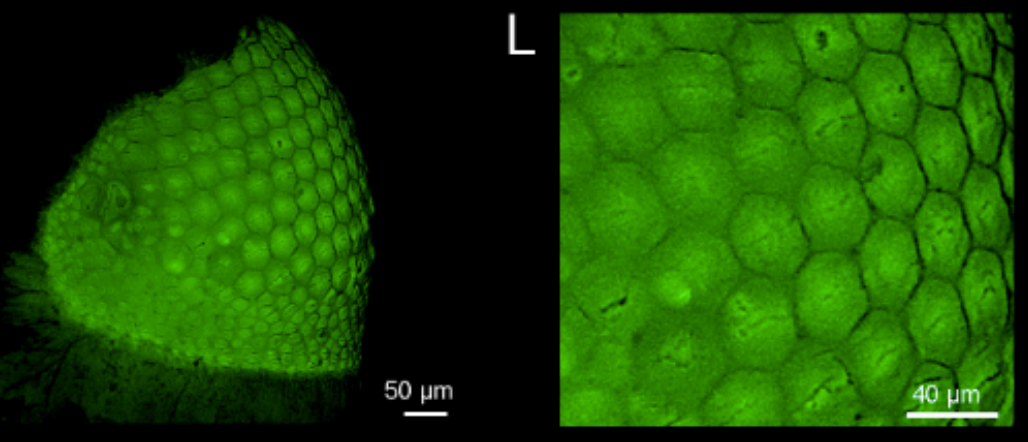

Figure 8. Raninoidea. A-F, Lyreididae; A-C, Lysirude nitidus (=Lyreidus bairdii), USNM 66638; A, dorsal view of female; B, SEM image of small right eye in a stout podophthalmite; $\mathrm{C}$, details of the cornea bearing hexagonal facets in hexagonal packing. D-F, Lysirude griffini, USNM 216726; D, dorsal view of male; E, SEM image of small right eye; $\mathrm{C}$, details of the cornea bearing hexagonal facets in hexagonal packing. G-I, Raninidae: Cyrtorhininae: Cyrtorhina granulosa, MNHN-IU-2016-2020 (= MNHN-B16181); G, dorsal view of female; H, SEM image of small right eye; I, details of the cornea bearing hexagonal facets in hexagonal packing. J-L, Raninidae: Symethinae: Symethis sp., uncatalogued specimen; J, dorsal view of male; K, Confocal microscope image of small right eye showing the different shapes and sizes of facets through the cornea; L, details of the cornea bearing hexagonal facets in hexagonal packing. Figure by J. Luque. 


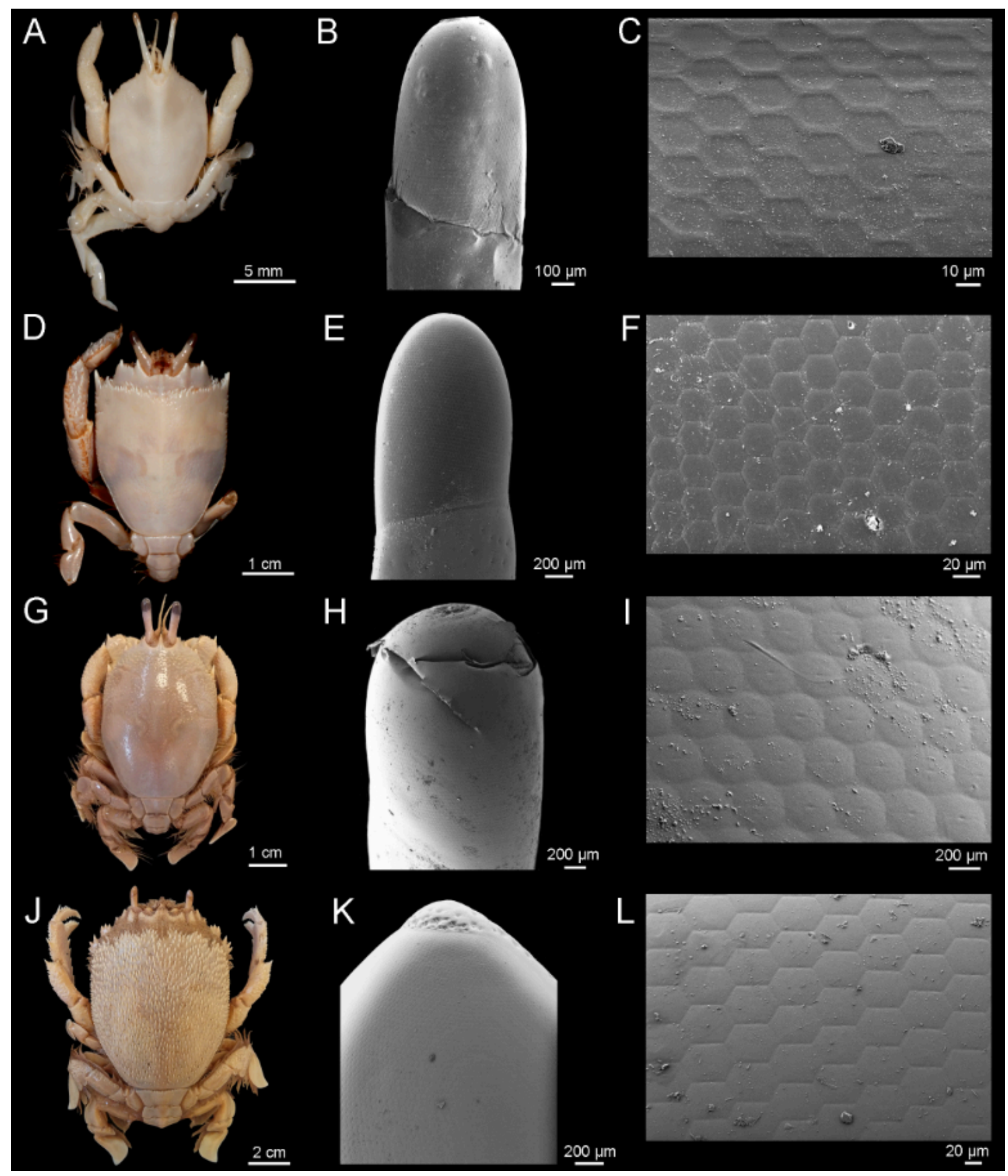

Figure 9. Raninoidea (cont.). A-I, Raninidae: Notopodinae; A-C, Cosmonotus grayi, MNHN-IU-2016-2024; A, dorsal view of male; $B$, SEM image of right eye; $C$, details of the cornea bearing hexagonal facets in hexagonal packing. D-F, Notopus dorsipes, MNHN-IU-2016-2023 (= MNHN-B7933); D, dorsal view of male; E, SEM image of left eye; F, details of the cornea bearing hexagonal facets in hexagonal packing. G-I, Ranilia muricata, USNM 121656; G, dorsal view of female; H, SEM image of right eye; I, details of the cornea bearing hexagonal to circular facets in hexagonal packing. J-L, Raninidae: Ranininae: Ranina ranina; J, dorsal view of specimen USNM 239219; K-L, specimen USNM 265062, female; K, SEM image of right eye; L, details of the cornea bearing hexagonal facets in hexagonal packing. Figure by J. Luque. 


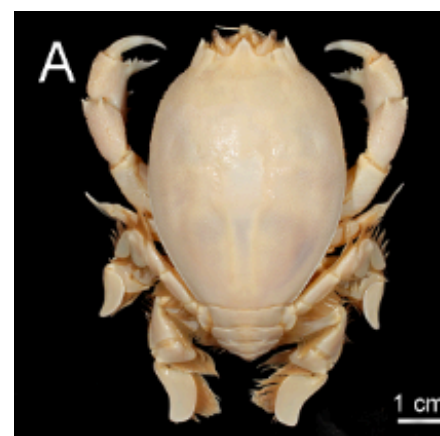

\section{B}
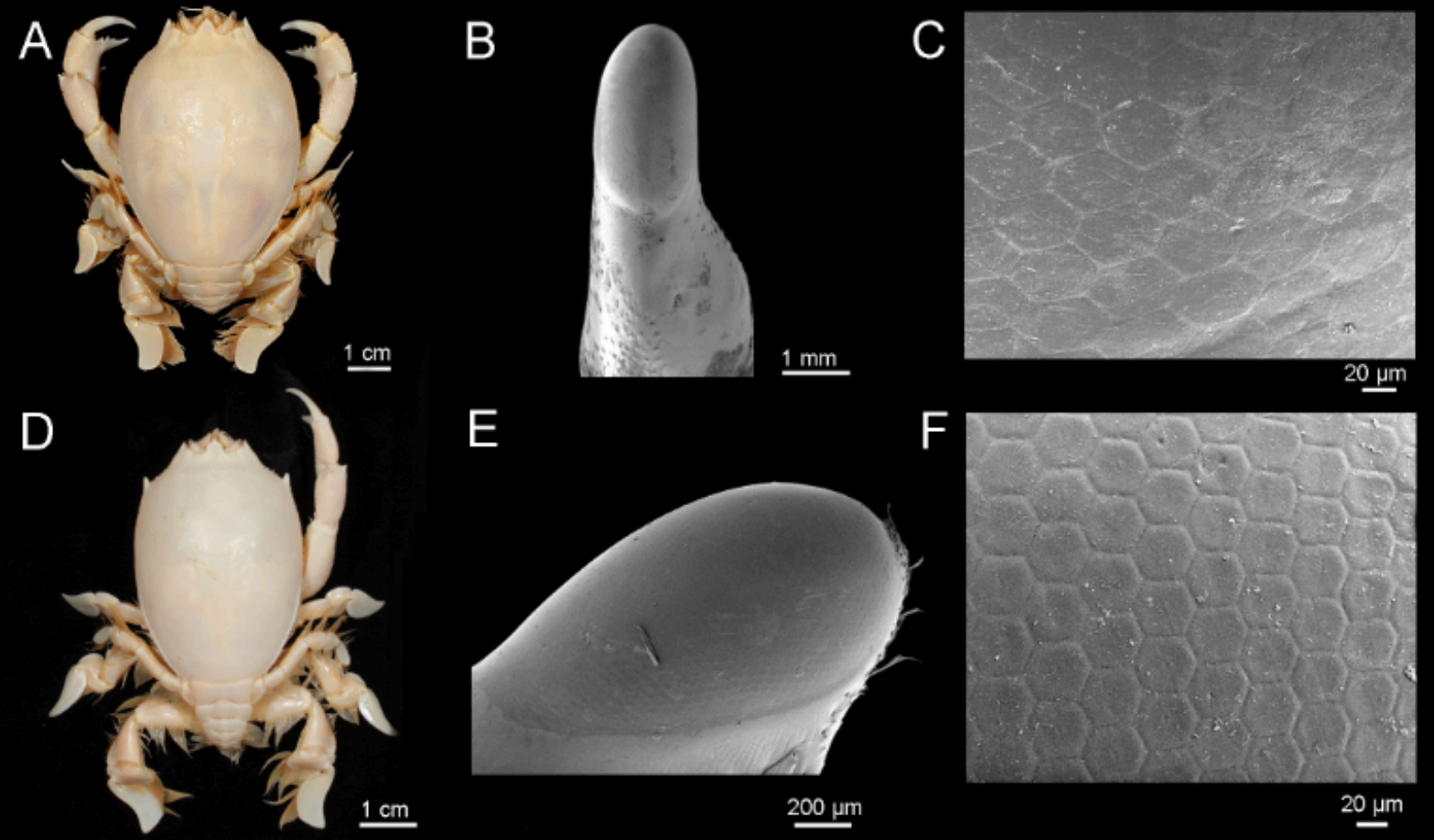

G
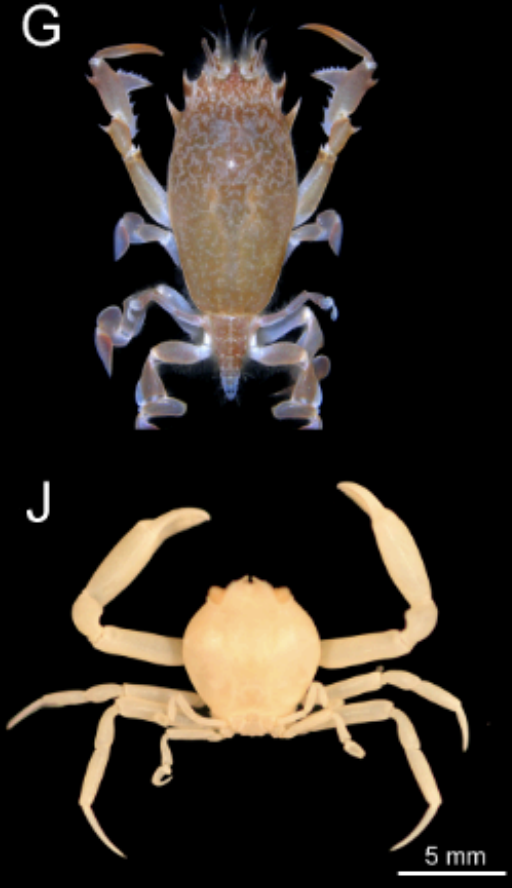

E
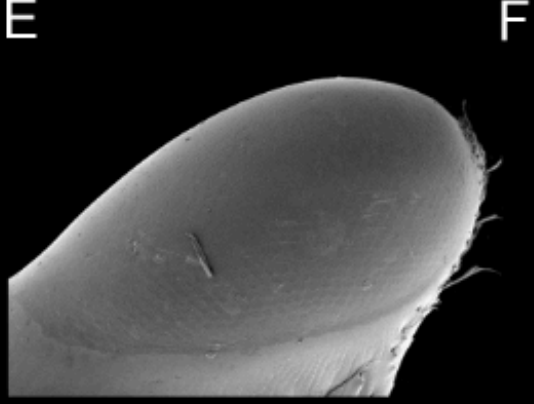

$200 \mu \mathrm{m}$

$\mathrm{H}$

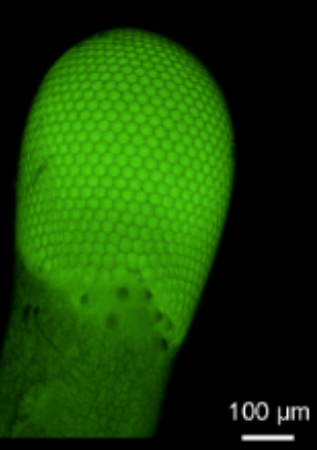

K

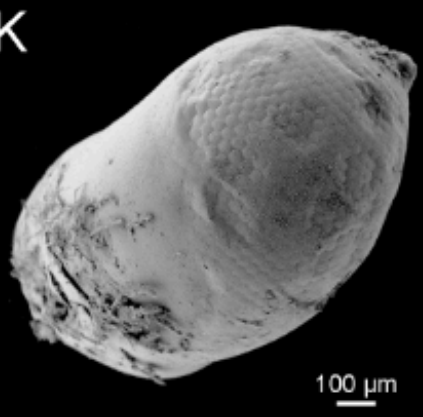

$\mathrm{F}$

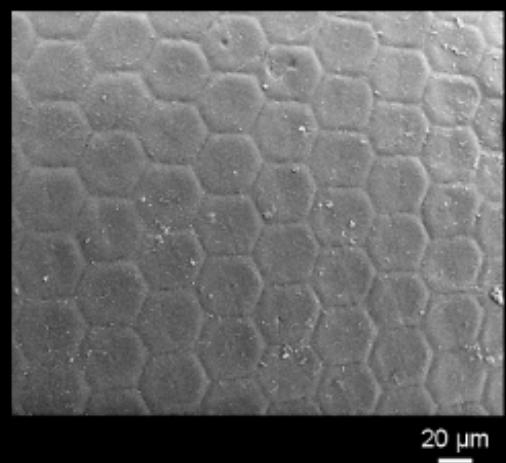

435 Figure 10. Raninoidea (cont.) and Cyclodorippoidea. A-I, Raninoidea: Raninidae: Raninoidinae: A-C, Notopoides latus, MNHN-IU-2016-2025 (= MNHN-B19110); A, dorsal view of male; B, SEM image of right eye and eyestalk; $\mathrm{C}$, details of the cornea bearing hexagonal facets in hexagonal packing. D-F, Notosceles viaderi, MNHN-IU-2016-2029 (= MNHN-B28964); D, dorsal view of male; E, SEM image of right eye; F, details of the cornea bearing hexagonal facets in hexagonal packing. G-I, Raninoides benedicti, specimen uncatalogued; G, dorsal view of male; $\mathrm{H}$, Confocal microscope image of right eye and eyestalk; I, close up of the cornea bearing hexagonal facets in hexagonal packing. J-L, Cyclodorippoidea: Cyclodorippidae: Clythrocerus nitidus, USNM 77380; J, dorsal view of male; $\mathrm{B}$, SEM image of small right eye; $\mathrm{C}$, details of the cornea bearing hexagonal facets in hexagonal packing. Figure by J. Luque. Photo G courtesy of Arthur Anker. 


\section{Eye preservation in fossil podotreme brachyurans}

445 †Callichimaeroidea

$\dagger$ Callichimaera perplexa has large globular eyes nearly as wide as long, resting in short eyestalks, and lacks orbits, orbital spines, or any protective structures (Fig. 11). The diameter of the cornea measures approximately $15 \%$ of the length of the carapace, and it is covered by small hexagonal to roundish facets in hexagonal packing with an average diameter of $34 \mu \mathrm{m}$ (Fig.

450 11C,F; Table 1). One small specimen exhibits a combination of facet shapes and arrays near the junction with the podophthalmite are sub-square, measure approximately $26 \mu \mathrm{m}$ in diameter, and are packed in a somewhat rectilinear array (Luque et al., 2019a).

\section{$\dagger$ Etyoidea}

455 Two specimens of $\dagger$ Xanthosia spp. (family $\dagger$ Etyidae) from the Lower Cretaceous (upper Albian, 105 Mya) Pawpaw Formation, Washita Group, Texas, USA, show small hemispherical eyes with reduced eyestalks, and a cornea bearing hexagonal facets packed hexagonally (Fig. 12A-F). The diameter of the cornea, preserved in one specimen (Fig. 12C), measures approximately 6\% of the width of the carapace, with an average facet diameter of $25 \mu \mathrm{m}$ (Table 1). The orbits are

460 half as long as the front, and about one-sixth of the carapace maximum width. They are not horizontal but diverge postero-laterally, and have two broad supraorbital fissures separated by a flat, rectangular intraorbital spine (Fig. 12A,B).

One specimens of $\uparrow$ Caloxanthus americanus (family $\dagger$ Feldmannidae) from the 'mid'Cretaceous (Cenomanian, 95 Mya) Grayson Formation, Texas, USA, shows round

465 hemispherical eyes resting in reduced eyestalks, and with corneae covered in small hexagonal facets packed hexagonally (Vega et al., 2014) (Fig. 12G-I). The diameter of the cornea measures approximately $10 \%$ of the width of the carapace, with an average facet diameter of XX $\mu \mathrm{m}$ (Table 1). As in $\dagger$ Xanthosia, the orbits are half as long as the front, and about one-sixth to oneseventh of the carapace maximum width, also diverging slightly postero-laterally. 
bioRxiv preprint doi: https://doi.org/10.1101/786087; this version posted October 7, 2019. The copyright holder for this preprint (which was not certified by peer review) is the author/funder, who has granted bioRxiv a license to display the preprint in perpetuity. It is made available under aCC-BY-NC-ND 4.0 International license.

Page -23-


Figure 11. Specimens of the crab $\dagger$ Callichimaera perplexa ( $\dagger$ Callichimaeroidea: $\dagger$ Callichimaeridae) with eyes preserved. Specimens coated with ammonium chloride, except for SEM images. A-C, Paratype IGM p881210,

ventral view; A, specimen showing the second antennae and left compound eye; B, SEM of anterior portion, showing the mxp3, antennae, and left compound eye; C, SEM image showing details of the facets. D-F: Paratype IGM p881207; D, specimen showing legs P2-P3, and right eye; E, SEM image of right eye; F, SEM close-up of the same eye, showing facets in hexagonal arrangement. G, Paratype IGM p881219, ventral view showing the chelipeds, legs P2-P5, both eyes, and rostrum. H, Paratype IGM p881211, showing right eye. I, Paratype IGM p881192,

480 showing a preserved eye. Abbreviations: A2: second antenna (antenna s.s.); Ca: carpus; Le-Re: left and right eyes; Me: merus; Pr: propodus. A, D, G-I coated with ammonium chloride; B-C, E-F, dry and uncoated SEM images. Figure by J. Luque. 


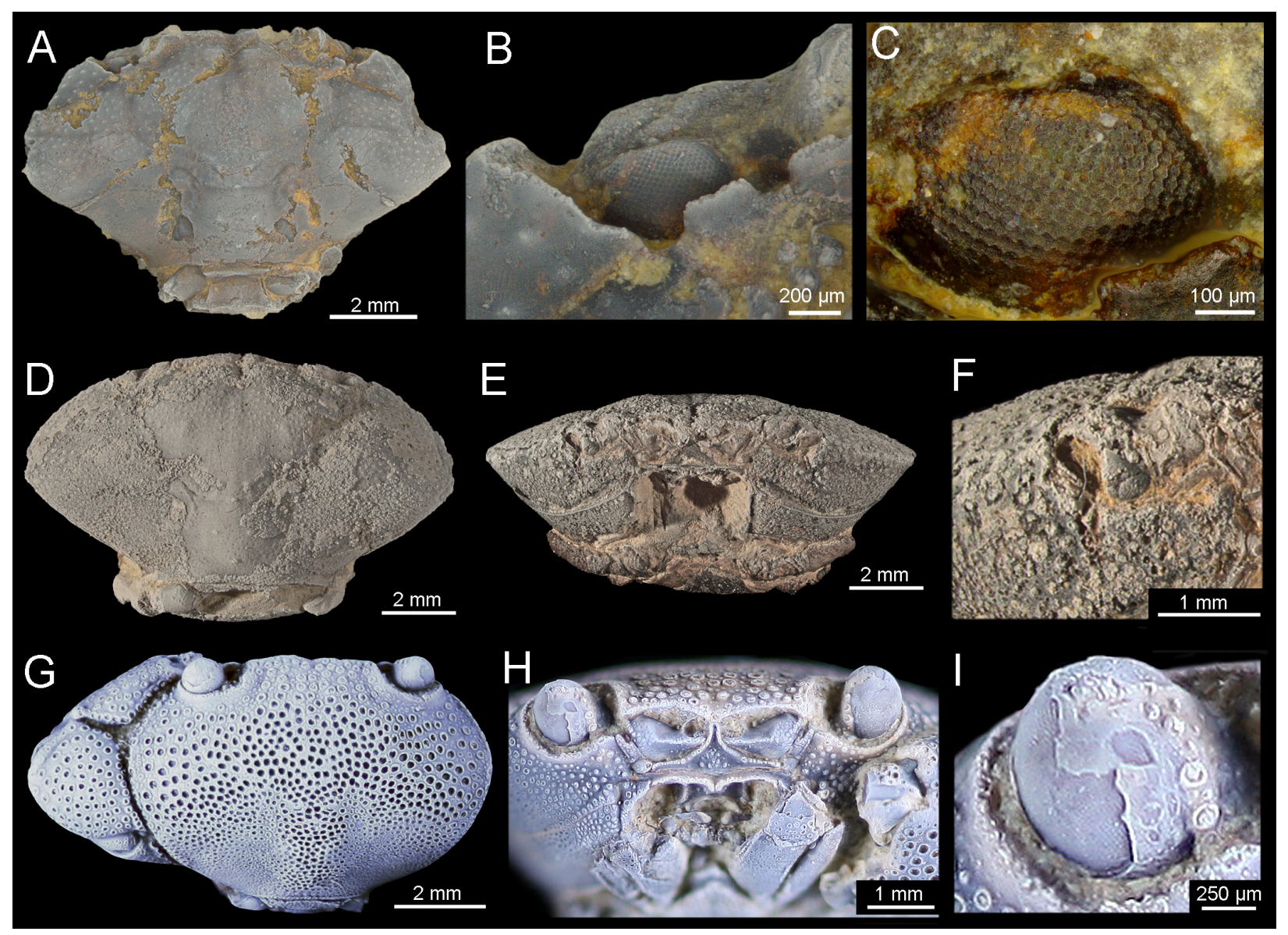

485 Figure 12. Specimens of the fossil crabs $\uparrow$ Xanthosia $(\dagger$ Etyoidea: $\dagger$ Etyidae) and $\dagger$ Caloxanthus $(\dagger$ Etyoidea:

$\dagger$ Feldmannidae) with eyes preserved. A-C, $†$ Xanthosia sp., specimen USNM PAL 706416 (1); A, dorsal view; B, close-up of dorsal left eye and orbital margin; $\mathrm{C}$, close-up of left compound eye bearing hexagonal facets in hexagonal array. D-F, $\dagger$ Xanthosia sp., specimen USNM PAL 706416 (2); D, dorsal view; E, frontal view showing the orbits; F, close-up of right eye with fragmented eye cornea bearing hexagonal facets in hexagonal packing. G-I, $\dagger$ Caloxanthus americanus, specimen NPL-62056; G, dorsal view; H, close-up of frontal view showing the hemispherical eyes; I, close-up of right compound eye bearing hexagonal facets in hexagonal array. All specimens photographed dry and coated with ammonium chloride, except for $\mathrm{C}$ (uncoated). Dagger $(\dagger)$ indicates extinct taxa. Images G-I courtesy of Liath Appleton (University of Texas). Figure by J. Luque.

\section{$†$ Necrocarcinoidea}

Three specimens of $\uparrow$ Cenomanocarcinus sp. Stenzel, 1945 (Raninoida: $†$ Necrocarcinoidea: $\dagger$ Cenomanocarcinidae) from the lower-mid Turonian (Upper Cretaceous, $\sim 90$ Mya) and the

500 lower Coniacian (Upper Cretaceous, $>88$ Mya) of Colombia, South America (Fig. 13A-I) exhibit the first and only recorded compound eyes with facets preserved in fossil raninoidans. The Turonian specimens (Fig. 13A-F) bear numerous small hexagonal facets in hexagonal packing. Their eyes rest on small eyestalks, and fit in their short orbits bearing two orbital fissures. The 
bioRxiv preprint doi: https://doi.org/10.1101/786087; this version posted October 7, 2019. The copyright holder for this preprint (which was not certified by peer review) is the author/funder, who has granted bioRxiv a license to display the preprint in perpetuity. It is made available under aCC-BY-NC-ND 4.0 International license.

Page -25-

Coniacian specimen, preserved in ventral view (Fig. 13G), preserves its right eye, has a roundish

505 cornea and a short eyestalk (Fig. 13H). As in the Turonian specimens, the eye portion that is exposed bears small hexagonal facets packed in a hexagonal arrangement (Fig. 13I).

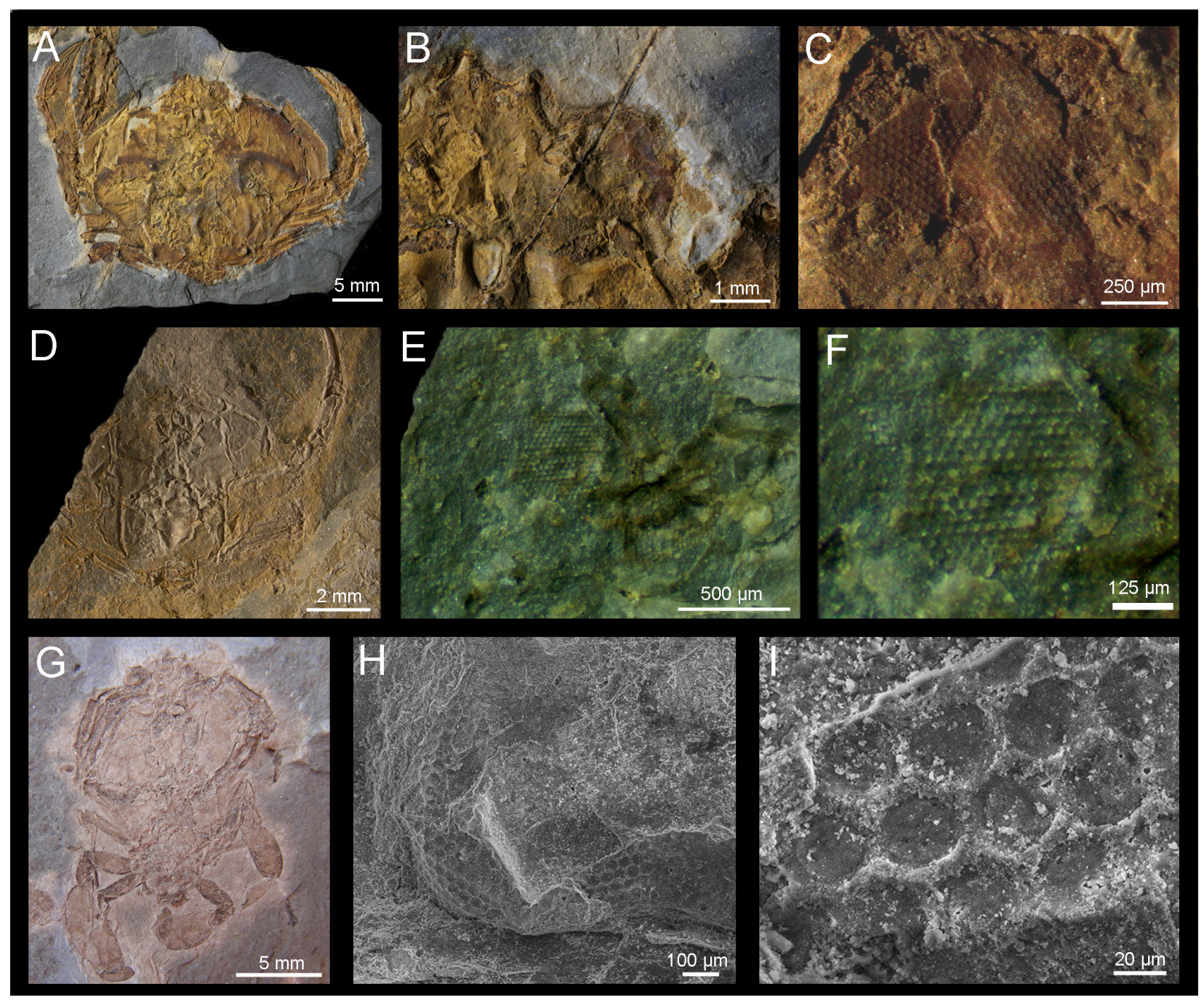

Figure 13. Specimens of the crab $\uparrow$ Cenomanocarcinus (Raninoida: $\uparrow$ Necrocarcinoidea: $\uparrow$ Cenomanocarcinidae) with eyes preserved. A-C, Specimen 32006-073, San Rafael Formation, lower Upper Cretaceous (Turonian, 90 Ma), Boyacá, Colombia; A, dorsal view; B, close-up of right eye; $\mathrm{C}$, close-up of right eye cornea bearing hexagonal facets in hexagonal packing. D-F, Specimen 320006-045, San Rafael Formation, lower Upper Cretaceous (Turonian,

$515 \sim 90 \mathrm{Ma}$ ), Boyacá, Colombia; D, dorsal view; E, close-up of left eye; F, close-up of left eye cornea bearing hexagonal facets in hexagonal packing. G-I, Specimen 320018-022, Conejo Formation, Upper Cretaceous (Coniacian, 85 Ma) of Boyacá, Colombia; G, ventral view of female; H, SEM image of right eye (Re); I, close-up of ventral right eye cornea showing small hexagonal facets in hexagonal packing. All specimens photographed dry, uncoated. Dagger $(\dagger)$ indicates extinct taxa. Figure by J. Luque. 
bioRxiv preprint doi: https://doi.org/10 1101/786087; this version posted October 7, 2019. The copyright holder for this preprint (which was not certified by peer review) is the author/funder, who has granted bioRxiv a license to display the preprint in perpetuity. It is made available under aCC-BY-NC-ND 4.0 International license.

Page -26-

\section{†Dakoticancroidea}

Four specimens of $\uparrow$ Avitelmessus grapsoideus from the Cenomanian (lower Upper Cretaceous, $\sim 95 \mathrm{Ma})$ of Texas, USA (Fig. 14; Table 1). The material examined from the USNM Paleobiology collections preserve very well the cuticle of the overall carapace, but the cuticle of the eye corneae are not preserved. These crab specimens are molts, and that the cuticle of the

525 corneae seems to be eroded away. Many of the eyes in these specimens were still covered by matrix, so the specimens were prepared mechanically to expose fresh eye surfaces in the search of facets. Yet, no facets in $\dagger$ Avitelmessus were positively identified (Fig. 14D, H, L), likely because the specimens seem to be exuviae. Although facet shape and packing is still unknown for dakoticancroids, we would expect dakoticancroids to have hexagonal facets in hexagonal packing

530 rather than square facets in orthogonal array. Some dakoticancroids have an orbital bulla reticularis (Bishop, 1984), which was not recognized in the studied $\uparrow$ Avitelmessus specimens.

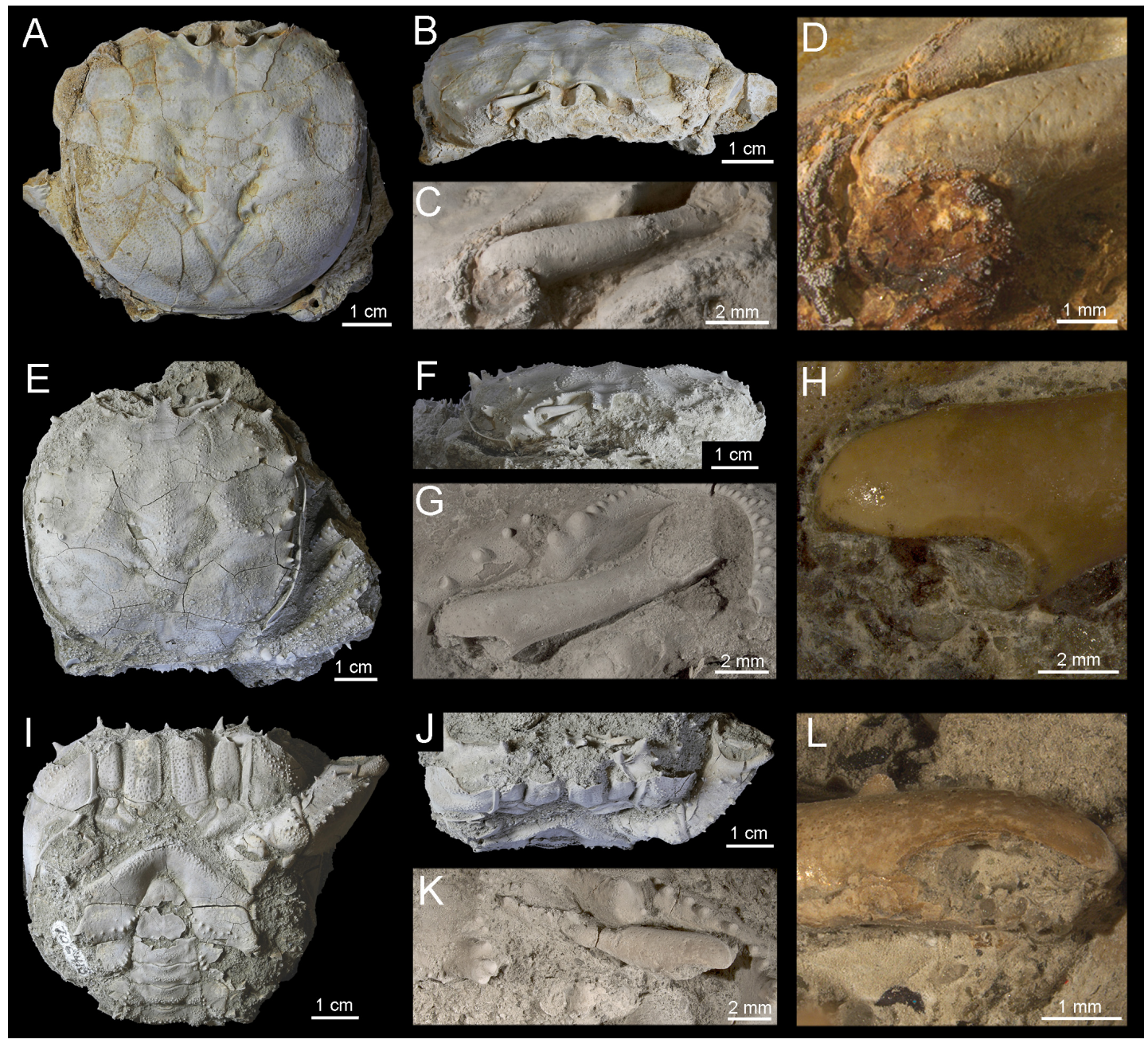


bioRxiv preprint doi: https://doi.org/10.1101/786087; this version posted October 7, 2019. The copyright holder for this preprint (which was not certified by peer review) is the author/funder, who has granted bioRxiv a license to display the preprint in perpetuity. It is made available under aCC-BY-NC-ND 4.0 International license.

Page -27-

Figure 14. Specimens of the crab $\dagger$ Avitelmessus grapsoideus ( $\dagger$ Dakoticancroidea: $\dagger$ Dakoticancridae) with eyes preserved. A-D, USNM PAL 706411, Ripley Formation, Upper Cretaceous (Maastrichtian), Mississippi, USA; A, dorsal view; B, frontal view; C, close-up of right eye and eyestalk; D, close-up of distal eye, cornea missing. E-H, USNM PAL 706412, Pender Formation, Upper Cretaceous (Maastrichtian), North Carolina, USA; E, dorsal view; F, frontal view; G, close-up of right eye and eyestalk; H, close-up of distal eye, cornea missing. IL, USNM PAL 706413, Pender Formation, Upper Cretaceous (Maastrichtian), North Carolina, USA; I, ventral view; J, frontal view; K, close-up of left eye and eyestalk; L, close-up of distal eye, cornea missing. All specimens photographed dry; A-C, E-G, I-K coated with ammonium chloride; D, H, L uncoated. Dagger ( $\dagger$ ) indicates extinct taxa. Figure by J. Luque.
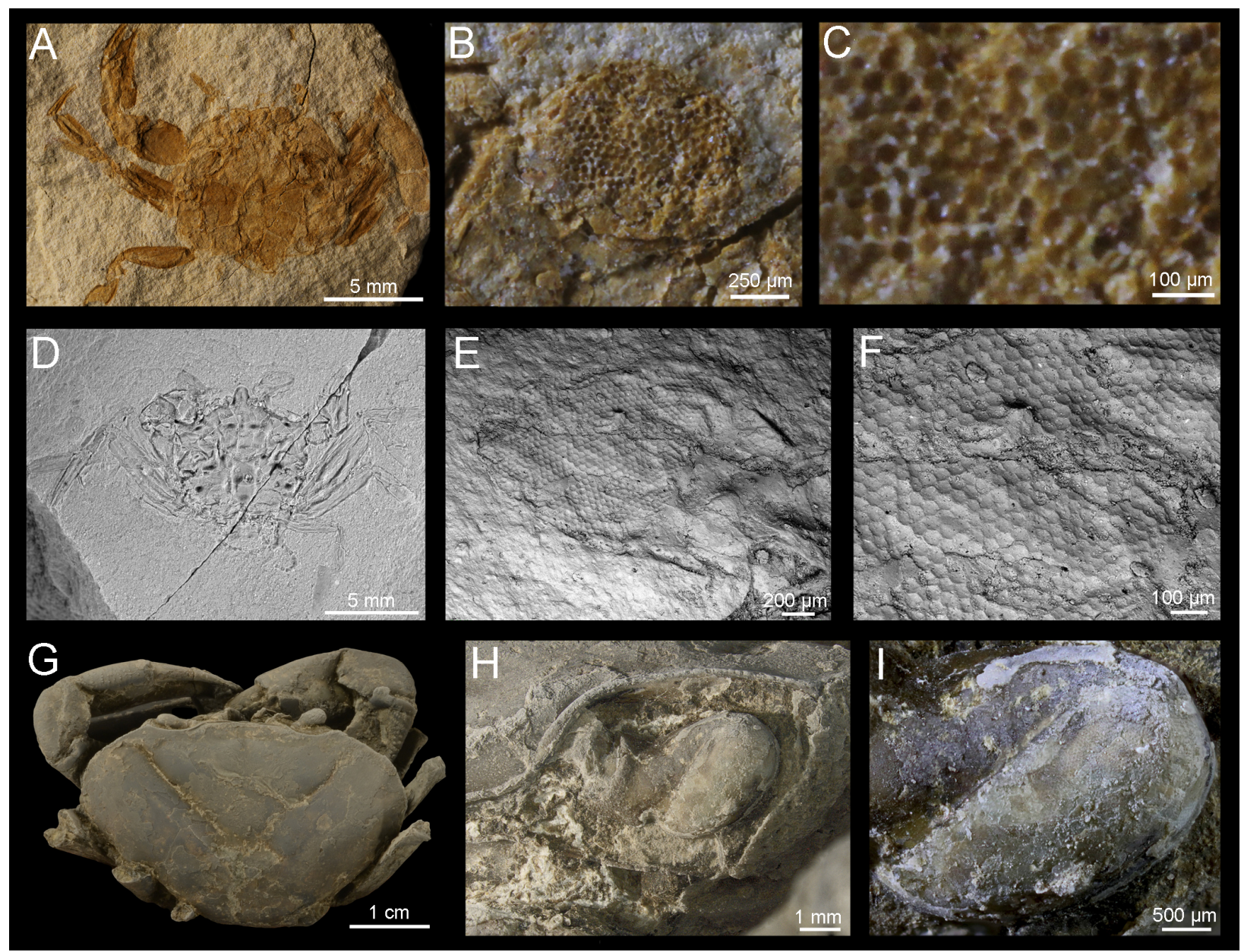

540 Cretaceous, 80-75 Mya) of Boyacá, Colombia; A, ventral view of specimen IGM p, 320010-002; B, close-up of eye and orbit; C, close-up of cornea bearing small hexagonal facets packed hexagonally. D-F: Eubrachyura sp., lower-mid Santonian (Upper Cretaceous, $\sim 85$ Mya) of Boyacá, Colombia; D, negative of male dorsal carapace showing the pereiopods, pleon, chelipeds, and large compound eyes; E, SEM image of compound eye bearing facets; F, close-up showing small hexagonal facets in hexagonal packing. G-I, Pseudothelphusoidea: Pseudothelphusidae

545 indet., uncatalogued specimen, Miocene of Panama, Panama; G, frontal view showing the fronto-orbital region, the $3^{\text {rd }}$ maxillipeds, and the compound eyes; $\mathrm{H}$, close-up of the left eye; I, details of the cornea preserving hexagonal facets in hexagonal packing, although hardly discernible. Dagger $(\dagger)$ indicates extinct taxa. Figure by J. Luque. 


\section{Eye preservation in fossil Eubrachyura}

550 Two fossil eubrachyurans indeterminate from the Santonian (Upper Cretaceous, 85 Mya) (Fig. 15A-C) and Campanian (Upper Cretaceous, 80-75 Mya) (Fig. 15D-F) of Colombia, have eyes bearing several small hexagonal facets packed in a hexagonal pattern. Likewise, a fossil freshwater crab from the Miocene of Panama (Neogene, 16 Mya) (Fig. 15G-I) has three-dimensional eyes bearing minute hexagonal facets in hexagonal packing, but hardly discernible (Fig. 15I).

\section{Facet shape and packing}

Lens packing differs significantly $(\mathrm{p}<0.0001)$ according to facet shape, i.e., all specimens examined that exhibit hexagonal packing also had hexagonal lens shape, and specimens with orthogonal packing possessed square lenses. The morphology of lens packing and facet shape

560 therefore covary in these taxa. As such, principal component analysis shows two distinct clusters representing hexagonal and square lens packing (Fig. 17). PC 1 records the largest amounts of variance (70.5\%), representing differences in lens packing. PC 2 (26.8\% of the total variance) represents error due to the curvature of the eye, an effect of imaging a curved surface, which affects the distances between landmarks and is uninformative regarding the packing arrangement

565 of ommatidia. The remaining six PCs account for less than $3 \%$ of the total variance and do not reveal any major trends in the packing of ommatidia.

\section{DISCUSSION}

570 The optical mechanisms in 'intermediate' podotremes - fossil or extant — are still poorly known, leaving a gap in our understanding of visual systems and ommatidia morphology between the two extremes of the brachyuran tree of life, i.e., the podotreme Homolodromioidea, Dromioidea, and Homoloidea in one hand, and the Eubrachyura in the other hand (Fig. 4). Based on a literature review, plus new data here presented, we examine some aspects of ommatidia packing and facet

575 shape across podotreme brachyurans, and what they can inform about the presence/absence of particular eye types in these groups. In addition, we discuss future directions related to the evolution of the ecology and development of crab eyes, photoreceptors, visual pigments, and vision loss across crabs, highlighting the lack of information available for intermediate crabs. 


\section{Ommatidial packing and facet shape in extant podotreme crabs}

External optical features alone cannot reveal details of eye light-path adaptations, however, they are useful for identifying the presence or absence of reflecting superposition eyes by observing their distinctive square facets in an orthogonal lattice (Fig. 2). Eyes of the apposition, refracting superposition, and parabolic superposition types have different internal structural mechanisms to

585 focus the light beams into the retina and form images, but they share the hexagonal to roundish external shape of the facets packed in a hexagonal lattice (Fig. 2). A hexagonal array efficiently packs cylindrical or hexagonal ommatidia into an eye, reducing the angular separation of the ommatidia to a minimum and increasing the eye resolution (Gaten, 1998). Reflecting superposition eyes, however, have distinctive square facets in an orthogonal array indicating

590 'mirror' optics with underlying square crystalline cones.

The eyes of Homolodromioidea, Dromiodea, and Homoloidea all share the plesiomorphic presence of adult eyes with square facets packed orthogonally, typical of reflecting superposition optics. Square facets are essential to the mirror mechanisms (Fincham, 1980; Vogt, 1980, and their presence in homolodromioid, dromiod, and homoloid crabs strongly contrasts with the lack

595 of reflecting superposition eyes in other fossil and extant podotremes and eubrachyurans.

Raninoids or frog crabs are one of the main brachyuran groups for which visual systems are largely unknown, in part due to their cryptic lifestyle and range of bathymetric depths (from 5 to $1000 \mathrm{~m}$ depth) (Luque, 2015), making their collection and study difficult. Extant raninoids are adapted for burrowing in sand or soft sediment (Bourne, 1922; Tucker, 1998; Luque, 2015).

600 Their particular 'frog-like' morphology with elongated carapace, a pleon that is partially exposed dorsally, elongated mouthparts, modified sternites, naked pleurae, and modified distal podomeres of their walking legs, are regarded as adaptations for their burrowing habit (Luque et al., 2019a). Gaten (1998) suggested that the relatively small eyes in Ranina are also an adaptation to a fossorial lifestyle. Extant raninids remain buried in the substratum during the day, emerging at 605 night to search for food (Skinner and Hill, 1986). Some taxa like Ranilia, Ranina, and particularly Cosmonotus, have relatively large eyes covered in small facets of nearly the same size throughout the cornea, and have long podophthalmite eyestalks that can be held outside the sediment when buried (Fig. 8). Conversely, raninid crabs like Symethis (Fig. 7J) show an 
extreme reduction of the eye and eyestalk, with the cornea enclosed in a reduced orbit and

610 bearing only a couple of hundred facets with different shapes, sizes, and packing (Fig. 7K,L). Symethis eyes seem to be degenerate and with poor resolving power.

Since frog crabs occupy an intermediate position between the earliest brachyuran branches (i.e., Homolodromioidea, Dromioidea, Homoloidea), and the more derived groups (i.e., Cyclodorippoidea and Eubrachyura), understanding raninoid optics is essential for testing hypotheses

615 of visual system distributions across brachyurans and their phylogenetic significance. The clear hexagonal facets in hexagonal packing (Figs 8-14), indicate the absence of reflecting superposition in Raninoidea as a whole. The presence of hexagonal facets in hexagonal packing in all raninoid species refutes the assumption by Gaten (1998) (see also table 1 in Porter and Cronin, 2009) that raninoids have mirror eyes just like in basal podotremes (Dromioidea, Homolodromioidea, and

620 Homoloidea). The incorrect inference for raninoids was obviously based on the erroneous supposition that 'Podotremata' is a monophyletic group whose members share the presence of reflecting superposition (mirror) eyes. Our findings, on the contrary, indicate that the visual systems present in raninoids are not of the mirror type but either the apposition, parabolic superposition, or refracting superposition type, thus more similar to the visual systems in eubrachyurans and 'higher'

625 podotremes (Figs 8-16). Furthermore, Cretaceous stem-group raninoidans such as $\uparrow$ Cenomanocarcinus (Raninoida: $\uparrow$ Necrocarcinoidea) also preserve eyes bearing small hexagonal facets packed in hexagonal arrangement (Fig. 13). †Cenomanocarcinidae belongs to a group of ancient crab-like raninoidans distantly related to $†$ Palaeocorystoidea, which themselves form a grade from which Raninoidea likely evolved (van Bakel et al., 2012; Karasawa et al., 2014; Luque, 2015;

630 Schweitzer et al., 2016; Luque et al., 2019a). This suggests that the loss of mirror optics in adults of the total group Raninoida (i.e., $\uparrow$ Necrocarcinoidea, $\uparrow$ Palaeocorystoidea, and Raninoidea) most likely occurred in their most recent common ancestor and all of its descendants, more than 90 Mya, which is the age of the fossil cenomanocarcinids with eyes.

The eyes of crabs in the extant superfamily Cyclodorippoidea are also understudied, in

635 part because these crabs are mostly found in deep waters and they have relatively small eyes. In species such as Krangalangia spinosa, the eyes are small (perhaps paedomorphic) and the corneal surface is covered by a small number of roundish facets in a hexagonal array (e.g., Scholtz and McLay, 2009, fig. 10). Other cyclodorippoids such as Clythrocerus nitidus (A. Milne-Edwards, 1880) have a clear hexagonal pattern of packing and facet shape (Fig. 10J-L). 
640 Thus, cyclodorippoid eyes conform with the absence of reflecting superposition eyes with square facets seen in more basal podotremes (except for those species with secondary eye reduction, see below under 'vision and eye loss in crabs').

\section{Ommatidial packing and facet shape in fossil podotreme crabs}

645 The morphology of ommatidial packing and facet shape is particularly useful when aiming to understand the fossil record of crustacean compound eyes, since only in a few exceptional cases internal eye structures are preserved (e.g., Vannier et al., 2016). In the enigmatic $\uparrow$ Callichimaera perplexa, hexagonal to round facets in hexagonal packing are the dominant feature throughout the cornea suggestive of apposition, parabolic superposition, or refracting superposition eyes

650 (Fig.11). One small specimen of $\dagger$ Callichimaera, however, has some proximal sub-square facets with rectilinear packing near the contact with the eyestalk (see in Luque et al., 2019a). In decapod crustaceans, the presence of two types of facets in the same eye is uncommon, with only a handful of fossil and extant species showing a combination of hexagonal and square facets. For instance, the larval to early juvenile instars of the shrimp Oplophorus spinosus (Brullé, 1839),

655 Systellaspis debilis (A Milne-Edwards, 1881), and a post-larval vent shrimp likely of Rimicaris exoculata Williams and Rona, 1986, show a mosaic of hexagonal and square facets likely associated with the transition from the larval apposition to the post-larval reflecting superposition eye type (Gaten and Herring, 1995; Gaten et al., 1998). Likewise, a fossil polychelidan lobster specimen from the Jurassic of France (Audo et al., 2019) has two facet shapes in the same eye,

660 but whether they represent a true regionalization of the eye or an artefact of the packing is unclear. The presence of squarish facets in one specimen of $\dagger$ Callichimaera thus may be the result of local facet packing rather than a true regionalization or transition between eye types. Furthermore, $\uparrow$ Callichimaera lacks any associated protective structures such as orbits or orbital spines (Fig. 11), indicating that its eyes must have remained exposed at all times even under

665 times of stress. Such exposed eyes and lack of orbits are mostly seen in crab megalopae, before they metamorphose into their post-larval stage. $†$ Callichimaera's large and unprotected globular eyes and its overall body form have been interpreted as possible paedomorphic retention of larval traits in adulthood (Luque et al., 2019a).

Similar to $†$ Callichimaeroidea, crabs of the superfamily $\dagger$ Etyoidea share with more 
670 inclusive podotremes and with eubrachyurans the absence of square facets in orthogonal array, typical of reflecting superposition eyes and present in basal podotreme lineages (Fig. 12). Vega et al. (2014) reported a specimen of $\uparrow$ Caloxanthus americanus (family $\uparrow$ Feldmannidae) also bearing hexagonal facets in hexagonal packing, which together with the specimens of $\uparrow$ Xanthosia spp. here illustrated confirm the presence of hexagonal facets in species of both etyoid families, unlike

675 the oldest brachyuran groups whose eyes are of the reflecting superposition type. Unlike $\uparrow$ Callichimaeroidea and $†$ Etyoidea, for which fossils preserving compound eyes with hexagonal facets have been reported, the corneal eyes of crabs from the superfamily $\uparrow$ Torynommoidea are yet to be discovered. Based on our current understanding of the distribution of visual systems across fossil and extant brachyurans, and given the phylogenetic position of torynommoids closer

680 to etyoids and raninoids (Luque et al., 2019a) (Fig. 16), we anticipate the presence of hexagonal facets in hexagonal packing in torynommoid crabs, instead of the square facets in orthogonal packing typical of early brachyuran lineages like dromioids, homolodromioids, and homoloids.

\section{Eye preservation in other fossil crabs}

685 Although preservation of crab eyes has been considered unusual (Klompmaker et al., 2017), we show that this is untrue. External and internal visual elements in fossil brachyurans do occur in several taxa from different groups, lithologies, and ages, and are underreported in the literature due to biases in recognizing them. Aside from $\dagger$ Callichimaera, facet-bearing eyes in fossil crabs have been found in the extinct etyoid $\uparrow$ Caloxanthus americanus Rathbun, 1935a, from the

690 Cenomanian of Texas (Vega et al., 2014), and in the fossil etyoids, cenomanocarcinids, and the eubrachyuran crabs here reported (Figs 11-14). Tanaka et al. (2009) reported isolated decapod eyes bearing hexagonal facets from the Aptian-Albian Romualdo Formation of Brazil (115-110 Mya), presumably from an achelatan phyllosoma larva, but the systematic placement remains uncertain. Also from the Romualdo Formation are some fossil brachyuran larvae bearing eyes

695 with facets, such as zoeae preserved as stomach contents in the fish $\uparrow$ Tharrhias (Maisey and Carvalho, 1995; Luque, 2015), and some fossil crab megalopae (Luque et al., 2019b). Both of these fossil crab larvae are modern-looking and have hexagonal facets packed hexagonally, just as modern crab larvae do (Fig. 5). Another fossil crab preserving eyes is $\dagger$ Ekalakia exophthalmos Feldmann et al., 2008 (Dromiacea: $†$ Glaessneropsidae), from the Campanian-Maastrichtian (70 
700 Mya) Pierre Shale Formation in the USA. Unfortunately, no corneae or facets are preserved in any known specimen. Miocene grapsoid crabs preserved in amber from Mexico (SerranoSánchez et al., 2016) also preserve facets, most likely hexagonal as in all other grapsoids. Overall, the fossil record indeed has several remarkably preserved eyes wherein ommatidia arrangements are available for interpretation. Considering the utility of this character for

705 resolving phylogenies, and the ability to discriminate the character using unbiased morphometrics (Fig 17), further effort is warranted in cataloguing fossil ommatidia shapes.

\section{Phylogenetic implications}

Although decapod larvae have apposition eyes (the simplest type of compound eye), adult

710 decapods of most shrimp, lobster, galatheoid anomuran, and early podotreme brachyuran clades share a unique reflecting superposition visual system not seen in other crustaceans outside Decapoda (Land, 1976; Scholtz and McLay, 2009; Tudge et al., 2012; Gaten et al., 2013). Noticeably, many decapods have independently retained larval apposition eyes (Gaten, 1998; Cronin and Porter, 2008; Porter and Cronin, 2009); or have evolved refractive or parabolic

715 superposition eyes while retaining hexagonal facet shape and packing (Nilsson, 1988).

Apposition and reflecting superposition eyes are more or less homogeneous across taxa, while the optical mechanisms in the parabolic and refracting superposition are more variable and with intermediate forms (Nilsson, 1983; Porter and Cronin, 2009).

Reflecting superposition eyes likely evolved only once in a recent common ancestor of

720 Decapoda during the Paleozoic. Among crabs, mirror optics are found in the earliest brachyuran lineages i.e., Homolodromioidea, Dromioidea, and Homoloidea, but are absent in Raninoidea, Cyclodorippoidea, and the most anatomically diverse and species-rich group of crabs: the Eubrachyura (Fig. 14). We should keep in mind, however, that ecology plays a crucial role in shaping the visual systems in an organism to better suit their biology, and a number of taxa with a

725 given eye type — or lack thereof - are likely to undergo adaptations to better suit their current ecological pressures (see below). 
bioRxiv preprint doi: https://doi.org/10.1101/786087; this version posted October 7, 2019. The copyright holder for this preprint (which was not certified by peer review) is the author/funder, who has granted bioRxiv a license to display the preprint in perpetuity. It is made available under aCC-BY-NC-ND 4.0 International license.

Page -34-

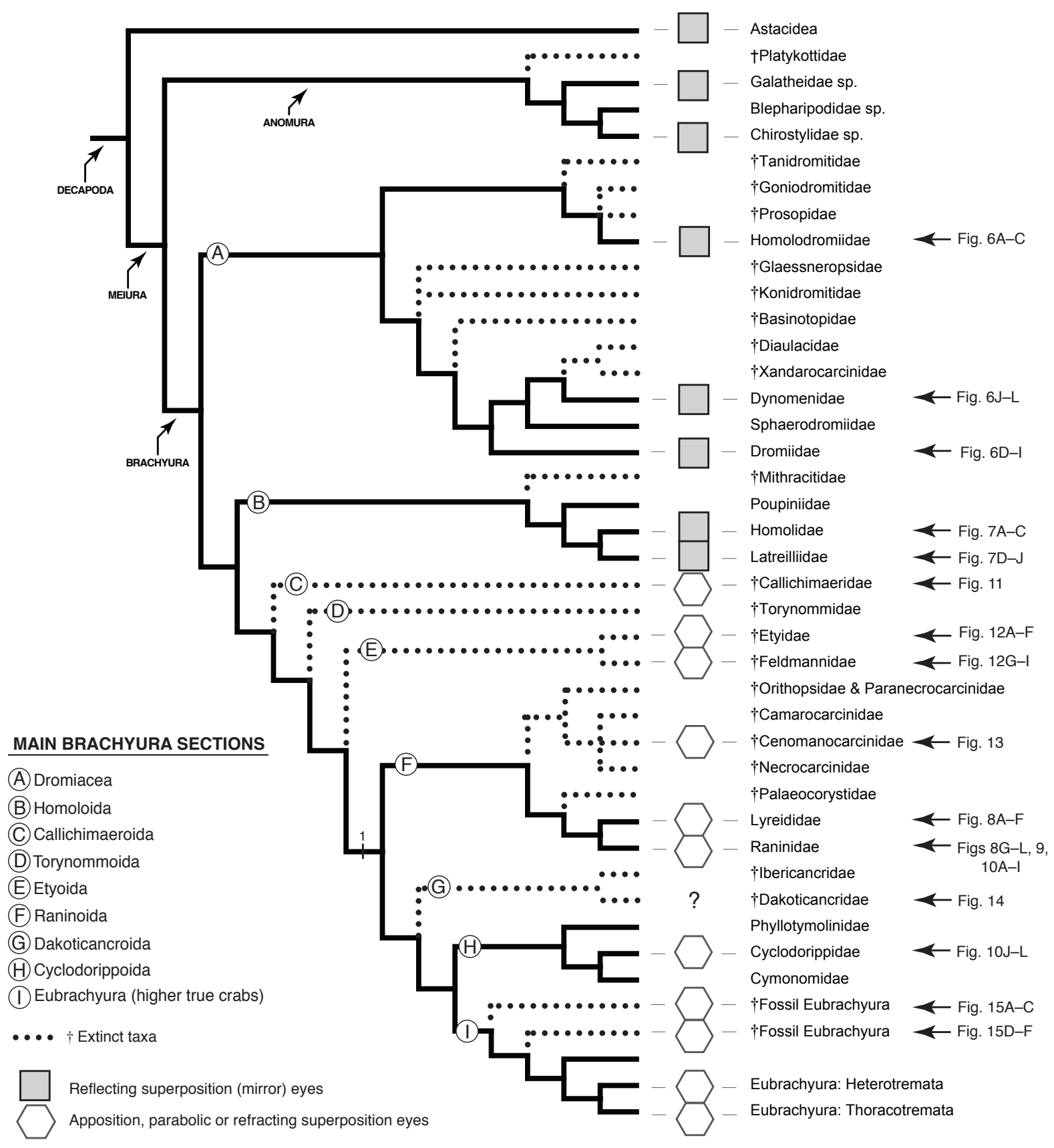

Figure 16. Distribution of visual systems in Brachyura. Hexagons: hexagonal facets with hexagonal packing, typical of apposition, parabolic superposition, and refracting superposition eyes. Squares: square facets in an orthogonal array typical of reflecting superposition eyes, or 'mirror' eyes. Only the eye facet shape of taxa examined in this studied are indicated. Figure by J. Luque. Tree topology modified after Luque et al. (2019a). 

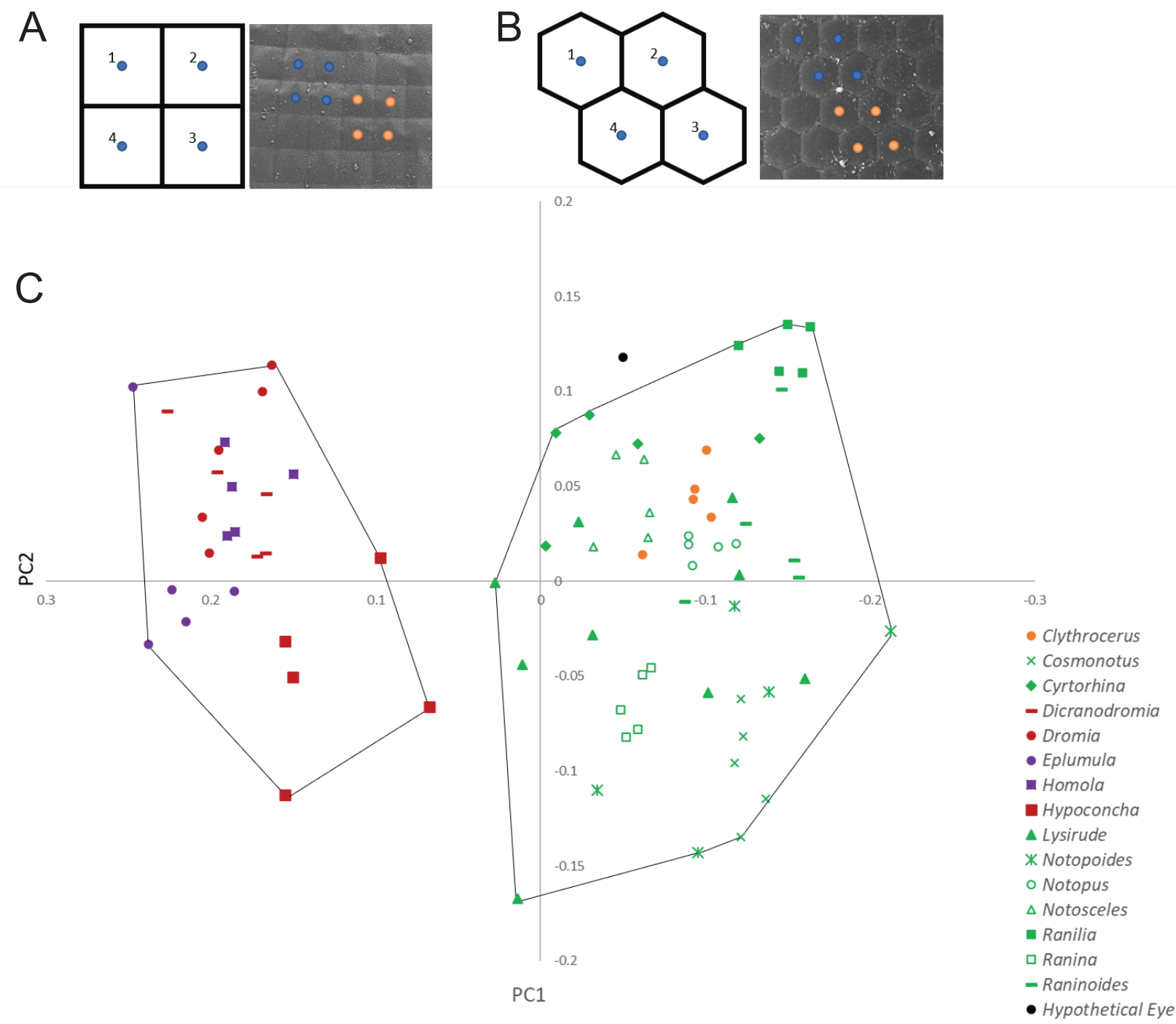

Figure 17. Principle component analysis resulting from geometric morphometric analysis of lens packing. A, Location of landmarks taken for geometric morphometric analysis in both orthogonal/square and hexagonally packed eyes. B, Results from GMM analysis. Two distinct groupings of eye types are revealed through GMM analysis, an orthogonal packing arrangement of square facets, and an hexagonally packed arrangement of hexagonal to roundish facets. Taxa are further grouped by facet shape (also orthogonal vs. hexagonal), showing that there is no overlap in morphology between lens packing and facet shape. Podotreme crab taxa with orthogonally arranged facets are represented by red and purple icons, and taxa with hexagonally arranged facets are represented by green and orange icons. Figure by K.M. Jenkins. 


\section{Other aspects of crab vision and future directions}

\section{Ecology and development of crab visual systems}

For any given species, living or fossil, the anatomy of the eye partly reflects selection pressures from the required visual tasks that must be performed within the light environments in which it lives. As in most crustaceans, brachyuran life history progresses through several stages living in different habitats, and therefore many aspects of the visual system (facet shape, optics, visual

740 pigments) may change throughout ontogeny. The early larval stages are generally pelagic and have transparent apposition eyes (Fig. 5). Larval apposition optics are specialized for open water habitats, and are thought to provide as much camouflage (predator avoidance) to the larva as possible by decreasing the pigmented portion of the retina to minimize its diameter. This results in a 'clear zone' between the cones and the rhabdom, thus the larval apposition eye functionally

745 mimics a superposition eye (Gaten, 1998; Feller and Cronin, 2014). At metamorphosis into the juvenile stage, these larval eyes are remodeled to form the diversity of compound eye types found in adult crabs, including reflective superposition optics in podotreme brachyurans (Gaten, 1998), and parabolic superposition optics in families of Eubrachyura (Nilsson, 1988). Conversely, crabs that inhabit consistently similar habitats throughout their life cycle do not seem to change their

750 visual sensitivity during metamorphosis (Cronin et al., 1995). For reflecting superposition eyes

(Fig. 2C, 5), note that the ommatidial facets are square as this is the only shape that can reflect light onto the retina.

Variations in the arrangement of eyes among species reflect specializations related to visual tasks within a given environment. Crabs that live in relatively flat environments (e.g.

755 Dotillidae, Goneplacidae, Heloeciidae, Ocypodidae, Mictyridae, Macrophthalmidae) tend to carry their eyes close together at the end of long eye stalks, or occasionally midway along an elongated eye stalk (as in the horned ghost crab Ocypode ceratophthalma). These taxa may have a need to resolve the distance of objects in their flat environments (Zeil et al., 1986). Crabs living on rocky shores or in mangrove forests (e.g., Grapsidae, Sesarmidae) tend to carry their eyes far apart on

760 short eye stalks (Zeil et al., 1986; Zeil et al., 1989; Zeil and Hemmi, 2006; Davie et al., 2015). Most occurrences of elongated eyestalks in brachyurans are from the Eubrachyura, although examples can also be found in groups such as the Latreillidae and Homolidae (Fig. 7), likely the 
result of different selective pressures to those associated with flat visual environments (Davie et al., 2015). There is no close phylogenetic relationship among groups with elongated eyestalks.

$\underline{\text { Vision and eye loss in crabs }}$

Although most crabs have functional eyes throughout some or all of their growth stages, from light-sensing to image forming, dramatic secondary reductions or complete losses of eyes has happened many times independently in crabs, and cannot be expected to inform phylogenies at a

770 high taxonomic level. These instances are generally limited to small groups of species that live in dark habitats such as the deep sea and caves. Species living in caves exhibit a range of eye reductions, and include representatives from Hymenosomatidae (e.g., Ng, 1991; Husana et al., 2011), Grapsidae (e.g., Ng et al., 1994), Potamidae (e.g., Yeo and Ng, 1999; Ng, 2017; Gecarcinucidae (e.g., Stasolla et al., 2015), and Parathelphusidae (e.g., Takeda and Ng, 2001;

775 Husana et al., 2009), among others. In smaller individuals of Cancrocaeca xenomorpha (Hymenosomatidae), the eye seems completely absent ( $\mathrm{Ng}, 1991$; $\mathrm{Ng}$ and Chuang, 1996), although larger individuals have discernible remnants of the eyes.

In the deep sea, many crustaceans have responded to low levels of light by either increasing eye size and visual sensitivity, or by undergoing reduction in visual structures leading 780 to vestigial eyes. As an example of eye reduction, the deep-sea crab Cymonomus bathamae Dell, 1971 (Cyclodorippoidea: Cymonomidae) has eyes that externally lack corneal facets, crystalline cones, and pigment cells, and the rhabdoms are irregular in shape and cell number (Chapman, 1977). Deep-sea hydrothermal vent crabs of the family Bythrograeidae like Austinograea williamsi Hessler and Martin, 1989 and Bythograea thermydron Williams, 1980 (see also Guinot, 785 1990) represent an extreme case of eye loss in crabs. In this group, the larval stages have limited pelagic capability, and the adults are completely benthic on the substrate adjacent to the vents. Larvae have conventional apposition compound eyes, which regress in the adults to form a featureless mass of tissue lacking cornea or lenses, and specialized for detecting the dim, red light emitted from hydrothermal vent water (Jinks et al., 2002). The adult vestigial tissue is located at 790 the base of the second antenna, while the orbits have become reduced and shallow as they serve no protective purpose for the eye anymore. 


\section{$\underline{\text { Photoreceptor and retinal structure }}$}

Photoreceptor cells are responsible for transduction of visual signals, and in arthropod compound

795 eyes are clustered together as ommatidia. Thus far, the photoreceptor arrangement has only been studied in eubrachyurans and other non-brachyuran decapods which possess mirror eyes, but not in podotremes. Eubrachyuran compound eyes in general follow the crustacean plan, containing eight photoreceptor cells (retinular cells) that fall in two anatomically distinct classes. Seven of the retinular cells (R1-7) contribute microvilli to a main receptor, that itself sits below a receptor

800 formed from the final, single retinular cell (R8, located distally within the rhabdom). These two receptor types are generally tuned to absorb medium and short wavelengths from the blue-green (R1-7) and violet or ultraviolet (UV) (R8) portions of the spectrum. Based on this photoreceptor anatomy and physiological measurements of receptor sensitivity (Cronin and Forward, 1988; Jordão et al., 2007), most crabs have been hypothesized to be functional dichromats (Horch et al.,

805 2002). However, both anatomical and molecular studies suggest as of yet uncharacterized potential diversity in brachyuran receptor morphology and sensitivity. In one of the only such studies conducted, expression of visual pigments in the Atlantic sand fiddler crab, Uca pugilator, found cell specific expression, suggesting functional diversity at the level of individual retinular cells (Rajkumar et al., 2010; further discussion below).

810 Anatomically, studies of the microvilli arrangement in fiddler crab receptors R1-7 have also suggested fine tuning (maximal separation of polarization contrast sensitivity) both regionally across the retina, and longitudinally across the length of each photoreceptor (Alkaladi et al., 2013). These anatomical studies suggest the potential for fine scale diversity within photoreceptors R1-7 that will affect overall chromatic and polarization sensitivity among species,

815 but requires studies across many more species to fully characterize patterns relative to phylogeny and ecology.

\section{Visual pigments and phototransduction}

From a molecular perspective, genetic and genomic methods have long advanced the field of

820 vision research. However, our current knowledge of the genes involved in vision and phototransduction, i.e., the conversion of light to electrochemical signals, is severely limited across decapod crustaceans (Henze and Oakley, 2015; Ramos et al., 2019; Zhang et al., 2019), 
with all crab data restricted to only a few eubrachyurans. Nevertheless, visual pigments play a critical role in the activation of the phototransduction signaling cascade, and consist of an opsin

825 protein bound to a chromophore (Pérez-Moreno et al., 2018). To date, the few studies that use molecular approaches aim to characterize the visual pigments, and more specifically opsin genes, present in the retina of the eyes and/or eyestalk. Yet those few impactful studies from the past three decades have advanced our knowledge of vision across eubrachyurans and lay the groundwork for future integrative research that combines genomics with other approaches, and 830 that will investigate podotreme genomic data.

One of the first studies of vision in brachyurans, and across crustaceans was carried out by Sakamoto et al. (1996), who aimed to test the hypothesis that crustaceans had multiple visual pigments in their retinas. Mounting evidence from spectral sensitivity studies suggested that decapods and stomatopods had multiple color receptors, and behavioral studies indicated fiddler

835 crabs could discriminate colors (Hyatt, 1974, 1975). To test for multiple visual pigments, Sakamoto et al. (1996) used cDNA sequencing in the shore crab, Hemigrapsus sanguineus, to successfully isolate two different opsin sequences, BcRh1 and BcRh2, and to investigate opsin expression via in situ hybridization. Two opsins were expressed in similar levels across all seven retinula cells (R1-7) that form the main rhabdom in each ommatidium. No definitive signal of 840 opsin expression was observed via in situ hybridization in the small distal retinular cell (R8) (Sakamoto et al., 1996), possibly due to the cell's smaller size (Stowe, 1980), or lack of an appropriate probe for a UV opsin. Visual sensitivity was further investigated using electroretinogram (ERG) measurements, suggesting the eye of $H$. sanguineus has a maximum sensitivity of 480nm. In the ERG, a slight shoulder was detected at 330-400nm possibly

845 indicating a second shorter-wavelength sensitivity, however this could not be confirmed with genetic results. It is plausible this signal was associated with the R8 cell, and possibly contained a third putative opsin sensitive to UV-wavelengths. Overall, this was one of the first molecular studies to demonstrate that two opsin proteins were present in one photoreceptor of the retina of the crab, H. sanguineus, with maximum absorbance in the blue-green range.

850 Over a decade later, Rajkumar et al. (2010) used molecular methods to investigate the spectral properties of fiddler crab eyes after behavioral (e.g., Hyatt, 1974, 1975; Detto, 2007; Detto and Backwell, 2009) and physiological studies (e.g., Hyatt, 1974; Scott and Mote, 1974; Horch et al., 2002; Jordão et al., 2007) provided contradictory evidence for the number of visual 
pigments in the retinular cells. Using cDNA sequencing methods, Rajkumar et al. (2010)

855 successfully characterized three distinct opsins (UpRh1, UpRh2, and UpRh3), from Uca (Leptuca) pugilator. In situ hybridization was used to examine expression levels in all eight retinula cells, and phylogenetic annotation was used to assign putative spectral sensitivities. UpRh1 and UpRh2 were expressed in the R1-7 cells, nested within a clade of arthropod opsins sensitive to middle wavelengths (MWS). Interestingly, UpRh1 was only expressed in five cells

860 whereas UpRh2 was expressed in three, indicating co-expression of these opsins occurs in one retinular cell. UpRh3 was expressed only in the R8 photoreceptor cell, and was phylogenetically placed within a clade of arthropod opsins sensitive to short wavelengths (UV). Therefore, $U$. pugilator has the opsin repertoire to discriminate color with possible trichromatic vision, if UpRh1 and UpRh2 have different peak absorbances. At the time of writing, the opsin sequences

865 and spectral sensitivities are only known from two species of brachyuran crabs, U. pugilator and H. sanguineus. Subsequent sequences from a handful of other species (restricted to eubrachyurans) are now available on NCBI, although none are linked to expression studies targeting the eyes in crabs.

To date, genomic investigations of brachyuran visual systems are lacking. While a

870 handful of studies have used RNA-seq to characterize the genes expressed within eyes or eyestalks, understanding the visual capabilities of crabs was not the main objective of this research (Hui et al., 2017; Lv et al., 2017; Yingdong et al., 2019). For example, tissue-specific RNA-seq from the eyestalks of Portunus trituberculatus and Eriocheir sinensis identified genes involved in molting and the circadian cycle, respectively. The data from E. sinensis are especially

875 useful due to the publication of a draft genome sequence (Song et al., 2016). A separate study extracted RNA from the vestigial eyes of the hydrothermal vent crab, Austinograea alayseae to investigate genes associated with living in extreme environments (Hui et al., 2017). From the vent crab, evidence was found for all genes involved in the fly phototransduction pathway and two distinct opsin sequences, however the expression levels were low. Although these studies did 880 not focus on visual ability, these data could be used in combination with more targeted approaches to advance the field of brachyuran vision.

Significantly, the presence of opsin sequences in the genome alone does not reveal anything about functionality, however these data lay the foundation for inferring the visual ability of any animal taxon. Integrative approaches that combine genomic, gene expression, 
885 physiological, microscopy, behavioral, and eventually gene editing studies, have the potential to revolutionize our understanding of vision across metazoans, however these approaches are still in their infancy across brachyurans, and data are entirely lacking for podotremes (the group with the most interesting and potentially phylogenetically informative variation in ommatidial morphology). As genomic data are generated for additional crab species, visual pigments should

890 be targeted by eye-specific transcriptomics and/or the design of genomic probes based on previous visual pigment annotations (Speiser et al., 2014; Schott et al., 2017; Pérez-Moreno et al., 2018). Tracing the evolution of photoreceptor genes and eye morphology across a robust crab tree could be an informative first step to reconstructing the evolutionary history of vision across this iconic group. 
Page -42-

\section{CONCLUSIONS}

Early brachyuran clades like the podotremes Dromioidea, Homolodromioidea, and Homoloida have reflecting superposition 'mirror' eyes, characterized by square facets packed in a rectilinear lattice. Mirror eyes are plesiomorphic for Decapoda, and are found in most shrimps, lobsters, several

900 anomurans, and the least inclusive brachyuran clades mentioned above. This supports the view that mirror eyes were present in the most recent common ancestor of crown group brachyurans.

Conversely, closer ingroup podotreme lineages like $\uparrow$ Callichimaeroidea, $†$ Etyoidea (i.e., $\dagger$ Feldmannidae, $\uparrow$ Etyiidae), $\uparrow$ Necrocarcinoidea (e.g., $\uparrow$ Cenomanocarcinidae), Raninoidea and Cyclodorippoidea, together with the so-called 'higher' true crabs or Eubrachyura, lack mirror eyes,

905 which may have been lost in a most recent common ancestor for those groups. The expression of eyes with hexagonal/roundish facets in hexagonal packing see across adult "higher" podotremes and eubrachyurans can be interpreted as a result of the secondary, paedomorphic retention of larval apposition eyes, or exaptation of a pre-adapted larval apposition eye to function as parabolic superposition eyes (Porter and Cronin, 2009). We conclude that the retention of apposition eyes in

910 'higher' podotremes and eubrachyurans has existed since at least the Early Cretaceous, more than 100 million years ago (Fig. 16). The distribution of eye types among brachyuran crabs provides evidence to refute the monophyly of podotremes, instead suggesting the groups that share apposition eyes form a paraphyletic grade with eubrachyurans, consistent with recent molecular and morphological phylogenetic works.

915 Ecology appears to be an important driver of visual systems among higher taxa, especially with respect to terrestrialization, colonization of fresh water, diurnal activity, specific dietary habits, and bathymetry, potentially leading to the independent loss of mirror eyes in many taxa. Ongoing work aims to shed light on whether predictable "rules" account for the potential convergent origins and/or losses of apposition and mirror eye types among true crabs through 920 time. 
Acknowledgements: J.L. thanks Rafael Lemaitre, Karen Reed, Mark Florence and Conrad Labandeira (USNM, USA) for providing access and loaning specimens from the Invertebrate Zoology and Paleobiology collections at the Smithsonian Institute. Peter Davie (QWM, Australia), for help accessing the QMW

925 Invertebrate Zoology collections at the Queensland Museum, Brisbane, Australia. To Daniéle Guinot, Paula Martin-Lefebre, and Laure Corbaire (MNHN Paris, France), for help accessing the Palaeontology and Invertebrate Zoology collections at the Muséum national d'Histoire naturelle, Paris, France. To Eric LazoWasem and Lourdes Rojas (Yale University, USA) for export permits and photography of specimens from the Yale Peabody Museum Invertebrate Zoology Collections. To Jody Martin (LACM, USA) for facilitating the

930 examination of extant crab eye samples of specimens deposited at the YPM and the LACM collections. To Michelle Pinsdorf (Department of Paleobiology, USNM) for help with the preparation of the USNM specimens of $\uparrow$ Avitelmessus grapsoideus, and to Liath Appleton and the Non-vertebrate Paleontology Lab at the Jackson School Museum of Earth History (University of Texas) for images of $\uparrow$ Caloxanthus americanus. John Douglass provided comments on early drafts of the manuscript. Jorge Ceballos (STRI, Panama), Arlene

935 Oatway and Nathan Gerein (UofA, Canada), and Elissa Martin (Yale Peabody Museum) provided SEM assistance. Marcela Gómez, Mauricio Pardo, and the Colombian Geological Survey supplied the export permits of the Colombian fossils here studied.

Funding: Partial funding for this study was provided to J.L. by the Smithsonian Tropical Research Institute Short-Term Fellowship Program (STRI-STF) (Panama), the American Museum of Natural History (AMNH) 940 Lerner Gray grant (USA), the Sedimentary Geology, Time, Environment, Paleontology, Paleoclimatology \& Energy (STEPPE) Student Travel Award Grant (USA), the Fondo Corrigan-ACGGP-ARES (Colombia), and the Natural Science and Engineering Research Council of Canada Graduate Scholarship (NSERC CGS-D). Additional support was provided by the Izaak Walton Killam Memorial Scholarship, the Andrew Stewart Memorial Graduate Prize, the University of Alberta President's Doctoral Prize of Distinction, the Devendra

945 Jindal Graduate Scholarship, the Alberta Society of Professional Biologists Graduate Scholarship, and the Kay Ball Memorial Graduate Student Research Travel Award (Canada), and the Natural Science and Engineering Research Council of Canada Postdoctoral Fellowship (NSERC PDF). Other support to J.L. via the Yale Institute for Biological Studies (YIBS), and NSERC Discovery Grants RGPIN 04863 to A.R.P. (Canada) and RGPIN-2014-06311 to W.T.A. (Canada). This work was also supported by the National Science Foundation 950 DEB \#1856679 to J.M.W. (USA).

Competing interests: The authors declare that they have no competing interests.

Data and materials availability/ accessibility: All data needed to evaluate the conclusions in the paper are present in the paper. 


\section{References}

Ahyong, S. T., Lai, J. C. Y., Sharkey, D., Colgan, D. J., and Ng, P. K. L. 2007. Phylogenetics of the brachyuran crabs (Crustacea: Decapoda): The status of Podotremata based on small subunit nuclear ribosomal RNA. Molecular Phylogenetics and Evolution, 45(2): 576-586.

960 fiddler crab rhabdoms. Journal of Comparative Physiology A, 199(2): 99-113.

Audo, D., Robin, N., Luque, J., Krobicki, M., Haug, J. T., Haug, C., Jauvion, C., and Charbonnier, S. 2019. Palaeoecology of Voulteryon parvulus (Eucrustacea, Polychelida) from the Middle Jurassic of La Voulte-sur-Rhône Fossil-Lagerstätte (France). Scientific Reports, 9(1): 5332.

Bishop, G. A. 1984. Orbital bulla reticularis: a new orbital structure of a Cretaceous crab. Journal of Crustacean Biology, 4(3): 514-517.

Bookstein, F. 1991. Morphometric Tools for Landmark Data. Cambridge, UK: Cambridge University Press.

Bourne, G. C. 1922. On the Raninidae: a study in carcinology. Journal of the Linnéan Society of London, Zoology, 35: 25-79.

970 Bouvier, E. L. 1894. Sur l'appareil branchial d'un crabe du groupe des Dromiens, la Dynomene filholi. Comptes rendus de la Société philomathique de Paris, 7: 6.

Chapman, D. M. 1977. Structure of the degenerate eyes of the deep-sea crab Cymonomus bathamae (Brachyura). Journal of the Royal Society of New Zealand, 7(3): 339-346.

Cronin, T. W., and Forward, R. B. 1988. The visual pigments of crabs. Journal of Comparative Physiology A: Neuroethology, Sensory, Neural, and Behavioral Physiology, 162(4): 463-478.

Cronin, T. W., Marshall, N. J., Caldwell, R. L., and Pales, D. 1995. Compound eyes and ocular pigments of crustacean larvae (Stomatopoda and Decapoda, Brachyura). Marine \& Freshwater Behaviour \& Phy, 26(2-4): 219-231.

Cronin, T. W., and Porter, M. L. 2008. Exceptional variation on a common theme: The evolution of crustacean compound eyes. Evolution: Education and Outreach, 1(4): 463-475.

Davie, P. J. F., Guinot, D., and Ng, P. K. L. 2015. Anatomy and functional morphology of BrachyuraTreatise on Zoology-Anatomy, Taxonomy, Biology. The Crustacea, Volume 9 Part C (2 vols), 11-163 pp. Brill.

De Haan, W. 1833-1850. Crustacea. In Siebold, P. F. v. (Ed) Fauna Japonica sive Descriptio Animalium, Quae in Itinere per Japoniam, Jussu et Auspiciis Superiorum, qui Summum in India Batava Imperium Tenent, Suscepto, Annis 1823-1830 Collegit, Notis, Observationibus et Adumbrationibus Illustravit, i-xvii, i-xxxi, ix-xvi, 1-243, pls. A-J, L-Q, 241-255, table 242 pp. Leiden. Lugduni-Batavorum.

Dell, R. K. 1971. Two new species of crabs of the genus Cymonomus from New Zealand (Crustacea: Brachyura). Records of the Dominion Museum, 7(8): 55-64.

Detto, T. 2007. The fiddler crab Uca mjoebergi uses colour vision in mate choice. Proceedings of the Royal Society B: Biological Sciences, 274: 2785-2790.

Detto, T., and Backwell, P. R. Y. 2009. The fiddler crab Uca mjoebergi uses ultraviolet cues in mate choice but not aggressive interactions. Animal Behaviour, 78: 407-411.

995 Dryden, I. L., and Mardia, K. V. 1998. Statistical Analysis of Shape. New York: John Wiley.

Feldmann, R. M., Schweitzer, C. E., and Wahl, W. 2008. Ekalakia (Decapoda: Brachyura): The preservation of eyes links Cretaceous crabs to Jurassic ancestors. Journal of Paleontology, 82(5): 1030-1034.

Feller, K. D., and Cronin, T. W. 2014. Hiding opaque eyes in transparent organisms: a potential role for larval eyeshine in stomatopod crustaceans. Journal of Experimental Biology, 217(18): 3263-3273.

Fincham, A. A. 1980. Eyes and classification of malacostracan crustaceans. Nature, 287(5784): 729-731.

Fincham, A. A. 1984. Ontogeny and optics of the eyes of the common prawn Palaemon (Palaemon) serratus (Pennant, 1777). Zoological Journal of the Linnaean Society, 81. 
Gaten, E., and Herring, P. J. 1995. Morphology of the reflecting superposition eyes of larval oplophorid shrimps. Journal of Morphology, 225(1): 19-29.

Gaten, E. 1998. Optics and phylogeny: is there an insight? The evolution of superposition eyes in the Decapoda (Crustacea). Contributions to Zoology, 67(4): 223-236.

Gaten, E., Herring, P. J., Shelton, P. M. J., and Johnson, M. L. 1998. Comparative morphology of the eyes of postlarval bresiliid shrimps from the region of hydrothermal vents. Biological Bulletin, 194(3): 267-280.

Gaten, E., Moss, S., and Johnson, M. L. 2013. The reniform reflecting superposition compound eyes of Nephrops norvegicus: optics, susceptibility to light-induced damage, electrophysiology and a ray tracing model. Advances in Marine Biology, 64: 107-148.

Goeke, G. D. 1985. Decapod Crustacea: Raninidae. Res. Camp. MUSORSTOM I-II. Philippines (1976, 1980), 2. Mémoires du Muséum National d'Histoire Naturelle, Paris (A, Zoologie), 133: 205-228.

Guinot, D. 1977. Propositions pour une nouvelle classification des Crustacés Décapodes Brachyoures. Comptes rendus hebdomadaires des séances de l'Académie des sciences, 285(Série D): 10491052.

Guinot, D. 1990. Austinograea alayseae sp. nov., Crabe hydrothermal découvert dans le bassin de Lau, Pacifique sud-occidental (Crustacea Decapoda Brachyura). Bulletin du Muséum National d'Histoire Naturelle, Paris-4e Série, 11(4): 879-903.

Guinot, D., and Richer de Forges, B. 1995. Crustacea Decapoda Brachyura: révision de la famille des Homolidae de Haan, 1839. Résultats des campagnes MUSORSTOM, 13: 283-517.

Hammer, Ø., Harper, D., and Ryan, P. 2001. PAST: Paleontological statistics software package for education and data analysis. Palaeontologia Electronica, 4: : 9. https://palaeoelectronica.org/2001_2001/past/issue2001_2001.htm.

Henderson, J. R. 1888. Report on the Anomura collected by H. M. S. Challenger during the years $1873-$ 1876. Report on the Scientific Results of the Voyage of HMS Challenger (Zoology), 27( $\mathrm{i}-\mathrm{xi}): 1-$ 221.

1030 Henze, M. J., and Oakley, T. H. 2015. The dynamic evolutionary history of pancrustacean eyes and opsins. Integrative and Comparative Biology, 55(5): 830-842.

Hessler, R. R., and Martin, J. W. 1989. Austinograea williamsi, new genus, new species, a hydrothermal vent crab (Decapoda: Bythograeidae) from the Mariana Back-Arc Basin, western Pacific. Journal of Crustacean Biology, 9(4): 645-661.

1035 Horch, K., Salmon, M., and Forward, R. 2002. Evidence for a two pigment visual system in the fiddler crab, Uca thayeri. Journal of Comparative Physiology A, 188: 493-499.

Hui, M., Song, C., Liu, Y., Li, C., and Cui, Z. 2017. Exploring the molecular basis of adaptive evolution in hydrothermal vent crab Austinograea alayseae by transcriptome analysis. PLoS One, 12(5): e0178417.

1040 Husana, D. E. M., Naruse, T., and Kase, T. 2009. Two new cavernicolous species of the genus Sundathelphusa from western Samar, Philippines (Decapoda: Brachyura: Parathelphusidae). Journal of Crustacean Biology, 29(3): 419-427.

Husana, D. E. M., Tan, S. H., and Kase, T. 2011. A new genus and species of anchialine Hymenosomatidae (Crustacea, Decapoda, Brachyura) from Samar, Philippines. Zootaxa, 3109(1): 1045 49-59.

Hyatt, G. W. 1974. Behavioural evidence for light intensity discrimination by the fiddler crab, Uca pugilator (brachyura, ocypodidae). Animal Behaviour, 22(4): 796-801.

Hyatt, G. W. 1975. Physiological and behavioral evidence for color discrimination by fiddler crabs (Bracyura, Ocypodidae, genus Uca). In Vernberg, F. J. (Ed) Physiologica Ecology and Estuarine Organisms, 333-365 pp. Columbia. University of South Carolina Press.

Jamieson, B. G. M., Guinot, D., and Richer de Forges, B. 1995. Phylogeny of the Brachyura (Crustacea, Decapoda): Evidence from spermatozoal ultrastructure. In Jamieson, B. G. M., Ausio, J. and Justine, J.-L. (Eds) Advances in Spermatozoal Phylogeny and Taxonomy. Mémoires du Muséum National d'Histoire Naturelle, 166, 265-283 pp. Paris. 
1055 Jinks, R. N., Markley, T. L., Taylor, E. E., Perovich, G., Dittel, A. I., Epifanio, C. E., and Cronin, T. W. 2002. Adaptive visual metamorphosis in a deep-sea hydrothermal vent crab. Nature, 420(6911): $68-70$.

1060

Jordão, J. M., Cronin, T. W., and Oliveira, R. F. 2007. Spectral sensitivity of four species of fiddler crabs (Uca pugnax, Uca pugilator, Uca vomeris and Uca tangeri) measured by in situ microspectrophotometry. Journal of Experimental Biology, 210(3): 447-453.

Karasawa, H., Schweitzer, C. E., and Feldmann, R. M. 2011. Phylogenetic analysis and revised classification of podotrematous Brachyura (Decapoda) including extinct and extant families. Journal of Crustacean Biology, 31(3): 523-565.

Karasawa, H., Schweitzer, C. E., Feldmann, R. M., and Luque, J. 2014. Phylogeny and classification of the Raninoida (Decapoda: Brachyura). Journal of Crustacean Biology, 34(2): 216-272.

Klompmaker, A. A., Portell, R. W., and Frick, M. G. 2017. Comparative experimental taphonomy of eight marine arthropods indicate distinct differences in preservation potential. Palaeontology.

Land, M. F. 1976. Superposition images are formed by reflection in the eyes of some oceanic decapod crustacea. Nature, 263: 764-765.

1070 Land, M. F. 1980. Compound eyes: old and new optical mechanisms. Nature, 287(681-686).

Land, M. F. 2000. Eyes with mirror optics. Journal of Optics A: Pure and Applied Optics, 2(6): R44.

Linnaeus, C. v. 1758. Systema Naturae per Regna Tria Naturae, Secundum Classes, Ordines, Genera, Species, cum Characteribus, Differentiis, Synonymis, Locis. Holmiae: Laurentii Salvii.

Luque, J. 2015. A puzzling frog crab (Crustacea: Decapoda: Brachyura) from the Early Cretaceous Santana Group of Brazil: Frog first or crab first? Journal of Systematic Palaeontology, 13(2): 153-166.

Luque, J., Feldmann, R. M., Vernygora, O., Schweitzer, C. E., Cameron, C. B., K.A., K., Vega, F. J., Duque, A., M., S., Palmer, A. R., and Jaramillo, C. 2019a. Exceptional preservation of midCretaceous marine arthropods and the evolution of novel forms via heterochrony. Science

$1080 \quad$ Advances, 5: eaav3875.

Luque, J., Xing, L., McKellar, R. C., Ossó, À., Charbonnier, S., Oliveira, G. R., Santana, W., Pinheiro, A. P., Saraiva, A. A., Clarck, E. G., and Briggs, D. E. G. 2019b. Exceptional preservation of midCretaceous true crabs and the early evolution of Eubrachyura7th Symposium on Cretaceous and Cenozoic Decapod Crustaceans. Ljubljana, Slovenia.

1085 Lv, J., Zhang, L., Liu, P., and Li, J. 2017. Transcriptomic variation of eyestalk reveals the genes and biological processes associated with molting in Portunus trituberculatus. PLoS One, 12(4): e0175315.

Maisey, J. G., and Carvalho, M. d. G. P. d. 1995. First records of fossil sergestid decapods and fossil brachyuran crab larvae (Arthropoda, Crustacea), with remarks on some supposed palaemonid fossils, from the Santana Formation (Aptian-Albian, NE Brazil). American Museum Novitates, 3132: 1-17.

Martin, J. W. 1990. Crabs of the family Homolodromiidae, ii. Dicranodromia felderi, new species, from the Western Atlantic, with notes on the type series of D. ovata A. Milne Edwards, 1880. Journal of Crustacean Biology, 10(4): 708-720.

1095 Milne-Edwards, A. 1880. Reports on the results of dredging, under the supervision of Alexander Agassiz, in the Gulf of Mexico, and in the Caribbean Sea, 1877, '78, '79, by the United States Coast Survey Steamer "Blake," Lieut.-Commander C.D. Sigsbee, U.S.N., and Commander J.R. Bartlett, U.S.N., commanding. VIII. Études préliminaires sur les crustacés. Bulletin of the Museum of Comparative Zoölogy at Harvard College, 8(1): 1-68.

1100 Milne-Edwards, A. 1881. Description de quelques crustacés macroures provenant des grandes profondeurs de la Mer des Antilles. Annales des Sciences Naturelles, 6e série, 11: 1-15.

Monod, T. 1956. Hippidea et Brachyura ouest-africains. Mémoires de l'Institut Français d'Afrique Noire, 45: $1-674$. 
Ng, P. K., Guinot, D., and Iliffe, T. M. 1994. Sesarmoides ultrapes new species, a remarkable sesarmine crab from caves in the Solomon Islands (Decapoda: Brachyura: Grapsidae). Crustacean research, 23: $12-22$.

Ng, P. K. 2017. Descriptions of two new cavernicolous species of Chinapotamon Dai \& Naiyanetr, 1994 (Crustacea: Brachyura: Potamidae) from China. Crustacean research, 46: 1-16.

Ng, P. K. L. 1991. Cancrocaeca xenomorpha, new genus apd species, a blind troglobitic freshwater

1110 hymenosomatid (Crustacea: Decapoda: Brachyura) from Sulawesi, Indonesia. Raffles Bulletin of Zoology, 39(1): 59-63.

Ng, P. K. L., and Chuang, C. T. 1996. The Hymenosomatidae (Crustacea: Decapoda: Brachyura) of southeast Asia, with notes on other species. Raffles Bulletin of Zoology, 44(3): 1-82.

Ng, P. K. L., Guinot, D., and Davie, P. J. F. 2008. Systema Brachyurorum: Part I. An Annotated Checklist of Extant Brachyuran Crabs of the World. The Raffles Bulletin of Zoology, 17: 1-286.

Nilsson, D. E. 1983. Evolutionary links between apposition and superposition optics in crustacean eyes. Nature, 302(5911): 818-821.

Nilsson, D. E., Hallberg, E., and Elofsson, R. 1986. The ontogenetic development of refracting superposition eyes in crustaceans: Transformation of optical design. Tissue and Cell, 18(4): 509-

$1120 \quad 519$

Nilsson, D. E. 1988. A new type of imaging optics in compound eyes. Nature, 332(6159): 76-78.

Nilsson, D. E. 1989. Optics and evolution in the compound eye. In Stavenga, D. G. and Hardie, R. C. (Eds) Facets of vision. Berlin. Springer.

Nilsson, D. E. 1990. Three unexpected cases of refracting superposition eyes in crustaceans. Journal of

1125 Comparative Physiology A, 167: 71-78.

Pérez-Moreno, J. L., DeLeo, D., Palero, F., and Bracken-Grissom, H. D. 2018. Phylogenetic annotation and genomic architecture of opsin genes in Crustacea. Hydrobiologia, 825(1): 159-175.

Porter, M. L., and Cronin, T. W. 2009. A shrimp's eye view of evolution: How useful are visual characters in decapod phylogenetics? In Martin, J. W., Crandall, K. A. and Felder, D. L. (Eds) Decapod Crustacean Phylogenetics: Crustacean Issues. 18, 183-195 pp.

Rajkumar, P., Rollmann, S. M., Cook, T. A., and Layne, J. E. 2010. Molecular evidence for color discrimination in the Atlantic sand fiddler crab, Uca pugilator. Journal of Experimental Biology, 213(24): 4240-4248.

Ramos, A. P., Gustafsson, O., Labert, N., Salecker, I., Nilsson, D. E., and Averof, M. 2019. Analysis of the genetically tractable crustacean Parhyale hawaiensis reveals the organisation of a sensory system for low-resolution vision. BMC Biology, 17(1): 1-19.

Rathbun, M. J. 1935a. Fossil Crustacea of the Atlantic and Gulf Coastal Plain. Geological Society of America, Special Paper(2): i-viii, 1-160.

$1140 \quad$ Proceedings of the Biological Society of Washington, 48: 1-4.

Rathbun, M. J. 1935b. Preliminary descriptions of seven new species of oxystomatous and allied crabs.

Rice, A. L. 1981. Crab zoeae and brachyuran classification: a re-appraisal. Bullulletin of the British Museum of Natural History (Zoology), 40: 287-296.

Rohlf, F. J. 2005. TpsDig, digitize landmarks and outlines, version 2.05Department of Ecology and Evolution, State University of New York at Stony Brook.

1145 Sakamoto, K., Hisatomi, O., Tokunaga, F., and Eguchi, E. 1996. Two opsins from the compound eye of the crab Hemigrapsus sanguineus. The Journal of Experimental Biology, 199: 441-450

Scholtz, G., and McLay, C. L. 2009. Is the Brachyura Podotremata a monophyletic group? In Martin, J. W., Crandall, K. A. and Felder, D. L. (Eds) Decapod Crustacean Phylogenetics. Crustacean Issues. 18, 417-435 pp.

1150 Schott, R. K., Panesar, B., Card, D. C., Preston, M., Castoe, T. A., and Chang, B. S. 2017. Targeted capture of complete coding regions across divergent species. Genome Biology and Evolution, 9(2): 398-414. 
Schweitzer, C. E., Karasawa, H., Luque, J., and Feldmann, R. M. 2016. Phylogeny and classification of Necrocarcinoidea Förster, 1968 (Brachyura: Raninoida) with description of two new genera. Journal of Crustacean Biology, 36(3): 338-372.

Scott, S., and Mote, M. I. 1974. Spectral sensitivity in some marine crustacea. Vision Research, 14: 659663.

Serrano-Sánchez, M. d. L., Guerao, G., Centeno-García, E., and Vega, F. J. 2016. Crabs (Brachyura: Grapsoidea: Sesarmidae) as inclusions in Lower Miocene amber from Chiapas, Mexico. Boletín de la Sociedad Geológica Mexicana, 68(1): 37-43.

Skinner, D. G., and Hill, B. J. 1986. Catch rate and emergence of male and female spanner crabs (Ranina ranina) in Australia. Marine Biology, 91: 461-465.

Song, L., Bian, C., Luo, Y., Wang, L., You, X., Li, J., and Wang, Z. 2016. Draft genome of the Chinese mitten crab, Eriocheir sinensis. GigaScience, 5(1): 5.

1165 Speiser, D. I., Pankey, M. S., Zaharoff, A. K., Battelle, B. A., Bracken-Grissom, H. D., Breinholt, J. W., Bybee, S. M., Cronin, T. W., Garm, A., Lindgren, A. R., Patel, N. H., Porter, M. L., Protas, M. E., Rivera, A. S., Serb, J. M., Zigler, K. S., Crandall, K. A., and Oakley, T. H. 2014. Using phylogenetically-informed annotation (PIA) to search for light-interacting genes in transcriptomes from non-model organisms. BMC Bioinformatics, 15(1): 350.

1170 Stasolla, G., Abbarchi, A., and Innocenti, G. 2015. Sundathelphusa spelaeophila, a new species of cavernicolous crab from Samar, Philippines (Decapoda: Brachyura: Gecarcinucidae). Raffles Bulletin of Zoology, 63: 448-453.

Stenzel, H. B. 1945. Decapod crustaceans from the Cretaceous of Texas. The University of Texas Publication, 4401: 401-477.

1175 Stowe, S. 1980. Spectral sensitivity and retinal pigment movement in the crab Leptograpsus variegatus (Fabricius). Journal of Experimental Biology, 87: 73-98.

Takeda, M., and Ng, P. K. 2001. The freshwater crab fauna (Crustacea, Brachyura) of the Philippines: VI. A new cavernicolous crab from Mindanao. Zoological Science, 18(8): 1123-1128.

Tanaka, G., Smith, R. J., Siveter, D. J., and Parker, A. R. 2009. Three-dimensionally preserved decapod larval compound Eyes from the Cretaceous Santana Formation of Brazil. Zoological Science, 26(12): 846-850.

Tsang, L. M., Schubart, C. D., Ahyong, S. T., Lai, J. C. Y., Au, E. Y. C., Chan, T.-Y., Ng, P. K. L., and Chu, K. H. 2014. Evolutionary history of true crabs (Crustacea: Decapoda: Brachyura) and the origin of freshwater crabs. Molecular Biology and Evolution, 31(5): 1173-1187.

1185 Tucker, A. B. 1998. Systematics of the Raninidae (Crustacea: Decapoda: Brachyura), with accounts of three new genera and two new species. Proceedings of the Biological Society of Washington, 111(2): 320-371.

Tudge, C. C., Asakura, A., and Ahyong, S. T. 2012. Infraorder Anomura MacLeay, 1838. In Schram, F. R. and Von Vaupel Klein, J. C. (Eds) Treatise on Zoology-Anatomy, Taxonomy, Biology. The

$1190 \quad$ Crustacea. Volume 9 Part B (70), 221-333 pp. Brill.

van Bakel, B. W. M., Guinot, D., Artal, P., Fraaije, R. H. B., and Jagt, J. W. M. 2012. A revision of the Palaeocorystoidea and the phylogeny of raninoidian crabs (Crustacea, Decapoda, Brachyura, Podotremata). Zootaxa, 3215: 1-216.

1195 preservation of eye structure in arthropod visual predators from the Middle Jurassic. Nature Communications, 7.

Vega, F. J., Jackson, J., and Ossó, À. 2014. Exceptional preservation of a late Cenomanian (Late Cretaceous) crab from Texas, U.S.A. Boletín de la Sociedad Geológica Mexicana, 66(1): 215221.

1200 Vogt, K. 1975. Zur Optik des Flußkrebsauges. Z Naturforsch, 32.

Vogt, K. 1980. Die Spiegeloptik des Flußkrebsauges. Journal of Comparative Physiology A, 135: 1-19.

Ward, M. 1942. A new genus and eight new species of Brachyura from Mauritius and the Chagos Archipelago. Mauritius Institute Museum, 2: 39-48, pls. 32-34. 
White, A. 1848. Short descriptions of new of little-known decapod Crustacea, 2. In: November 23, 1847. William Yarrell, Esq. Vice President, in the chair. Proceedings of the Zoological Society of London, (15)179 ((1847)): 222-228.

Williams, A. B. 1980. A new crab family from the vicinity of submarine thermal vents on the Galapagos Rift (Crustacea: Decapoda: Brachyura). Proceedings of the Biological Society of Washington, 93(2): 443-472.

1210 Williams, A. B., and Rona, P. A. 1986. Two new caridean shrimps (Cresillidae) from a hydrothermal field on the Mid-Atlantic Ridge. Journal of Crustacean Biology, 6: 446-462.

Wolfe, J. M., Breinholt, J. W., Crandall, K. A., Lemmon, A. R., Moriarty Lemmon, E., Timm, L. E., Siddall, M. E., and Bracken-Grissom, H. D. 2019. A phylogenomic framework, evolutionary timeline and genomic resources for comparative studies of decapod crustaceans. Proceedings of the Royal Society B, 286: 20190079.

Yeo, D. C., and Ng, P. K. 1999. Erebusa calobates, new genus, new species, a troglobitic crab (Brachyura: Potamidae) from Laos. Journal of Crustacean Biology, 19(4): 908-916.

Yingdong, L., Zhibin, H., Qiuxin, S., Yingying, Z., Hua, W., Jing, D., Weibin, X., Xin, L., and Shudong, L. 2019. Comparative transcriptome analysis provides insights into the molecular basis of circadian cycle regulation in Eriocheir sinensis. Gene, 694: 42-49.

1220

Zeil, J., Nalbach, G., and Nalbach, H. O. 1986. Eyes, eye stalks and the visual world of semi-terrestrial crabs. Journal of Comparative Physiology A, 159(6): 801-811.

Zeil, J., Nalbach, G., and Nalbach, H.-O. 1989. Spatial vision in a flat world: optical and neural adaptations in arthropods. In Singh, R. N. and Strausfeld, N. J. (Eds) Neurobiology of Sensory Systems, 123-137 pp. New York. Plenum Press.

Zeil, J., and Hemmi, J. M. 2006. The visual ecology of fiddler crabs. Journal of Comparative Physiology A, 192(1): 1-25.

Zhang, X., Yuan, J., Sun, Y., Li, S., Gao, Y., Yu, Y., Liu, C., Wang, Q., Lv, X., Zhang, X., and Ma, K. Y. 2019. Penaeid shrimp genome provides insights into benthic adaptation and frequent molting. Nature Communications, 10(1): 356. 
Table 1. List of extant podotreme and fossil brachyuran specimens studied. Abbreviations: CL: carapace maximum length; CorL: cornea length; CorW: cornea width/diameter; Cw: carapace maximum width; FD: facet diameter; mm: millimeters; $\mu$ m: microns. Dagger $(\dagger)$ indicates extinct taxa.

\begin{tabular}{|c|c|c|c|c|c|c|c|c|c|}
\hline Collection ID & Taxon & Locality & Facet shape / array & $\begin{array}{l}\text { CorW } \\
(\mathrm{mm})\end{array}$ & $\begin{array}{l}\text { CorL } \\
(\mathrm{mm})\end{array}$ & $\begin{array}{c}\mathrm{CL} \\
(\mathrm{mm})\end{array}$ & $\begin{array}{c}\mathrm{CW} \\
(\mathrm{mm})\end{array}$ & $\begin{array}{c}\text { CorW/ } \\
\text { CL }\end{array}$ & $\begin{array}{c}\text { FD } \\
(\mu \mathrm{m})\end{array}$ \\
\hline & Homolodromiidae: & North Atlantic Ocean, Caribbean Sea (see in & & & & & & & \\
\hline USNM 252207 & $\begin{array}{l}\text { Dicranodromia felderi } \\
\text { Dromiidae: Dromia }\end{array}$ & Martin, 1990) & Square / orthogonal & 1.53 & 1.50 & 23.00 & 17.70 & 6.65 & 35.00 \\
\hline USNM 1277452 & personata & Indet & Square / orthogonal & 1.66 & 1.56 & 28.60 & 34.00 & 5.80 & 35.77 \\
\hline USNM 186466 & $\begin{array}{l}\text { Dromiidae: Hypoconcha sp. } \\
\text { Dynomenidae: Dynomene }\end{array}$ & North Atlantic Ocean, United States & Square / orthogonal & 1.66 & 1.15 & 17.90 & 18.80 & 9.27 & 39.90 \\
\hline USNM 121402 & filholi & $\begin{array}{l}\text { West Africa, Annobion Island } \\
\text { North Atlantic Ocean, Suriname, Northeast }\end{array}$ & Square / orthogonal & 1.00 & 1.00 & 12.30 & 15.60 & 8.13 & 29.90 \\
\hline USNM 1185786 & $\begin{array}{l}\text { Homolidae: Homola minima } \\
\text { Homolidae: Latreillopsis }\end{array}$ & of Paramaribo & Square / orthogonal & 2.00 & 2.00 & 27.40 & 24.40 & 7.30 & 30.60 \\
\hline QMW.17070 & $\begin{array}{l}\text { bispinosa } \\
\text { Latreillidae: Eplumula }\end{array}$ & Off Tully Heads, NE Queensland & Square / orthogonal & 1.80 & 1.90 & 23.40 & 16.50 & 7.69 & 35.00 \\
\hline USNM 74587 & $\begin{array}{l}\text { phalangium } \\
\dagger \text { Callichimaeridae: }\end{array}$ & $\begin{array}{l}\text { Off Honshun Island, Japan } \\
\text { Cenomanian-Turonian Churuvita Group, }\end{array}$ & Square / orthogonal & 1.52 & 1.18 & 11.50 & 6.80 & 13.22 & 24.50 \\
\hline IGM p881192 & $\begin{array}{l}\dagger \text { Callichimaera perplexa } \\
\uparrow \text { Callichimaeridae: }\end{array}$ & $\begin{array}{l}\text { Boyacá, Colombia } \\
\text { Cenomanian-Turonian Churuvita Group, }\end{array}$ & Indet. & & & & & & \\
\hline IGM p881207 & $\begin{array}{l}\dagger \text { Callichimaera perplexa } \\
\text { †Callichimaeridae: }\end{array}$ & $\begin{array}{l}\text { Boyacá, Colombia } \\
\text { Cenomanian-Turonian Churuvita Group, }\end{array}$ & Indet. & 2.70 & & 17.00 & 8.60 & 15.88 & \\
\hline IGM p881208 & $\begin{array}{l}\dagger \text { Callichimaera perplexa } \\
\text { †Callichimaeridae: }\end{array}$ & $\begin{array}{l}\text { Boyacá, Colombia } \\
\text { Cenomanian-Turonian Churuvita Group, }\end{array}$ & Indet. & 1.90 & 1.70 & & & & \\
\hline IGM p881209a & $\begin{array}{l}\dagger \text { Callichimaera perplexa } \\
\text { †Callichimaeridae: }\end{array}$ & $\begin{array}{l}\text { Boyacá, Colombia } \\
\text { Cenomanian-Turonian Churuvita Group, }\end{array}$ & Indet. & 2.00 & & 12.53 & & 15.96 & \\
\hline IGM p881210 & $\begin{array}{l}\dagger \text { Callichimaera perplexa } \\
\dagger \text { Callichimaeridae: }\end{array}$ & $\begin{array}{l}\text { Boyacá, Colombia } \\
\text { Cenomanian-Turonian Churuvita Group, }\end{array}$ & Indet. & 1.35 & & 10.70 & 6.50 & 12.62 & \\
\hline IGM p881211 & $\begin{array}{l}\dagger \text { Callichimaera perplexa } \\
\dagger \text { Callichimaeridae: }\end{array}$ & $\begin{array}{l}\text { Boyacá, Colombia } \\
\text { Cenomanian-Turonian Churuvita Group, }\end{array}$ & Indet. & 2.70 & & 16.20 & 9.80 & 16.67 & \\
\hline IGM p881219 & $\dagger$ Callichimaera perplexa & Boyacá, Colombia & Indet. & 1.50 & 1.50 & & & & \\
\hline
\end{tabular}




\begin{tabular}{|c|c|c|c|c|c|c|c|c|c|}
\hline Collection ID & Taxon & Locality & Facet shape / array & $\begin{array}{l}\text { CorW } \\
(\mathrm{mm})\end{array}$ & $\begin{array}{l}\text { CorL } \\
(\mathrm{mm})\end{array}$ & $\begin{array}{c}\mathrm{CL} \\
(\mathrm{mm})\end{array}$ & $\begin{array}{c}\mathrm{CW} \\
(\mathrm{mm})\end{array}$ & $\begin{array}{c}\text { CorW/ } \\
\text { CL }\end{array}$ & $\begin{array}{c}\text { FD } \\
(\mu \mathrm{m})\end{array}$ \\
\hline IGM p881220 & $\begin{array}{l}\text { †Callichimaeridae: } \\
\dagger \text { Callichimaera perplexa }\end{array}$ & $\begin{array}{l}\text { Cenomanian-Turonian Churuvita Group, } \\
\text { Boyacá, Colombia }\end{array}$ & $\begin{array}{l}\text { Hexagonal to squarish } \\
\text { / hexagonal to } \\
\text { orthogonal }\end{array}$ & 0.81 & 0.70 & 6.60 & 3.80 & 12.27 & 33.10 \\
\hline $\begin{array}{l}\text { USNM PAL } \\
706416(1) \\
\text { USNM PAL }\end{array}$ & $\dagger$ Etyidae: $†$ Xanthosia sp. & Albian Pawpaw Formation, Texas, USA & Hexagonal / hexagonal & & & & & & \\
\hline $706416(2)$ & $\begin{array}{l}\dagger \text { Etyidae: } † \text { Xanthosia sp. } \\
\dagger \text { Feldmannidae: }\end{array}$ & $\begin{array}{l}\text { Albian Pawpaw Formation, Texas, USA } \\
\text { Cenomanian Grayson Formation, Texas, }\end{array}$ & Hexagonal / hexagonal & & & & & & \\
\hline NPL-62056 & $\begin{array}{l}\dagger \text { Caloxanthus americanus } \\
\dagger \text { Cenomanocarcinidae: }\end{array}$ & $\begin{array}{l}\text { USA } \\
\text { Turonian San Rafael Formation, Boyacá, }\end{array}$ & Hexagonal / hexagonal & & & & & & \\
\hline $320006-045$ & $\begin{array}{l}\text { †Cenomanocarcinus sp. } \\
\text { †Cenomanocarcinidae: }\end{array}$ & $\begin{array}{l}\text { Colombia } \\
\text { Turonian San Rafael Formation, Boyacá, }\end{array}$ & Hexagonal / hexagonal & & & & & & \\
\hline $320006-073$ & $\begin{array}{l}\text { †Cenomanocarcinus sp. } \\
\text { †Cenomanocarcinidae: }\end{array}$ & $\begin{array}{l}\text { Colombia } \\
\text { Coniacian Conejo Formation, Boyacá, }\end{array}$ & Hexagonal / hexagonal & & & & & & \\
\hline 320018-022 & $\begin{array}{l}\dagger \text { Cenomanocarcinus sp. } \\
\text { Lyreididae: Lysirude nitidus }\end{array}$ & $\begin{array}{l}\text { Colombia } \\
\text { Isla Tortugas, Station \#25. About } 16 \mathrm{~min}\end{array}$ & Hexagonal / hexagonal & 0.75 & 0.75 & & & & 35.00 \\
\hline USNM 66638 & (Lyreidus bairdii) & $\begin{array}{l}\text { South of \#2 Red Buoy } \\
\text { North Pacific Ocean; United States; }\end{array}$ & Hexagonal / hexagonal & 0.40 & 0.76 & 33.00 & 18.45 & 1.21 & 23.00 \\
\hline $\begin{array}{l}\text { USNM } 216726 \\
\text { MNHN-IU-2016- }\end{array}$ & Lyreididae: Lysirude griffini & California, San Francisco Bay & Hexagonal / hexagonal & 0.60 & 0.70 & 39.00 & 22.70 & 1.54 & 32.80 \\
\hline $\begin{array}{l}2020(=\text { MNHN- } \\
\text { B16181) }\end{array}$ & $\begin{array}{l}\text { Raninidae: Cyrtorhina } \\
\text { granulosa }\end{array}$ & Golfe de Guinée, I. Principe & Hexagonal / hexagonal & 0.90 & 1.00 & 48.10 & 41.70 & 1.87 & 35.00 \\
\hline $\begin{array}{l}\text { Uncataloged } \\
\text { MNHN-IU-2016- }\end{array}$ & Raninidae: Symethis sp. & Las Perlas, Panamá & Hexagonal / hexagonal & 0.40 & 0.38 & 28.70 & 18.00 & 1.38 & 35.00 \\
\hline $\begin{array}{l}2024 \\
\text { MNHN-IU-2016- }\end{array}$ & Raninidae: Cosmonotus grayi & Nouvelle Caledonie, Lagon Nord & Hexagonal / hexagonal & 0.47 & 0.90 & 9.35 & 7.90 & 5.03 & 20.00 \\
\hline $\begin{array}{l}2023 \text { (= MNHN- } \\
\text { B7933) }\end{array}$ & Raninidae: Notopus dorsipes & Musée de Manille, Philippines & Hexagonal / hexagonal & 0.97 & 1.44 & 31.50 & 25.70 & 3.08 & 26.50 \\
\hline USNM 121656 & Raninidae: Ranilia muricata & Florida, East Coast Near Fort Pierce & Hexagonal / hexagonal & 1.69 & 2.50 & 40.20 & 30.10 & 4.20 & 32.00 \\
\hline USNM 265062 & Raninidae: Ranina ranina & Taiwan, Tou Cheng Li Lan & Hexagonal & 3.41 & 5.6 & 68.5 & 56 & 4.97 & 52.00 \\
\hline
\end{tabular}




\begin{tabular}{|c|c|c|c|c|c|c|c|c|c|}
\hline Collection ID & Taxon & Locality & Facet shape / array & $\begin{array}{l}\text { CorW } \\
(\mathrm{mm})\end{array}$ & $\begin{array}{l}\text { CorL } \\
(\mathrm{mm})\end{array}$ & $\begin{array}{c}\text { CL } \\
(\mathrm{mm})\end{array}$ & $\begin{array}{c}\mathrm{CW} \\
(\mathrm{mm})\end{array}$ & $\begin{array}{c}\text { CorW / } \\
\text { CL }\end{array}$ & $\begin{array}{c}\text { FD } \\
(\mu \mathrm{m})\end{array}$ \\
\hline \multicolumn{10}{|l|}{ MNHN-IU-2016- } \\
\hline \multicolumn{10}{|l|}{2025 (= MNHN- } \\
\hline B19110) & Raninidae: Notopoides latus & Iles Seychelles & Hexagonal / hexagonal & 1.50 & 2.84 & 56.00 & 42.00 & 2.68 & 41.60 \\
\hline \multicolumn{10}{|l|}{ MNHN-IU-2016- } \\
\hline 2029 (= MNHN- & Raninidae: Notosceles & & & & & & & & \\
\hline B28964) & viaderi & French Polynesia & Hexagonal / hexagonal & 0.80 & 1.50 & 43.20 & 29.90 & 1.85 & 38.60 \\
\hline Uncatalogued & Raninidae: Raninoides & & & & & & & & \\
\hline \multirow[t]{2}{*}{ specimen } & benedicti & Las Perlas Archipielago, Panama & Hexagonal / hexagonal & 0.50 & 0.40 & & & & 26.00 \\
\hline & Cyclodorippidae: & & & & & & & & \\
\hline USNM 77380 & Clythrocerus nitidus & Florida, Poustales Plateau & Hexagonal / hexagonal & 0.66 & 0.66 & 5.90 & 6.50 & 11.19 & 35.00 \\
\hline USNM PAL & $\dagger$ Dakoticancridae: & Maastrichtian Ripley Formation, Mississippi, & & & & & & & \\
\hline 706411 & $\dagger$ Avitelmessus grapsoideus & USA & Unknown & & & & & & \\
\hline USNM PAL & $\dagger$ Dakoticancridae: & Maastrichtian Pender Formation, North & & & & & & & \\
\hline 706412 & $\dagger$ Avitelmessus grapsoideus & Carolina, USA & Unknown & & & & & & \\
\hline USNM PAL & $\dagger$ Dakoticancridae: & Maastrichtian Pender Formation, North & & & & & & & \\
\hline \multirow[t]{2}{*}{706413} & $\dagger$ Avitelmessus grapsoideus & Carolina, USA & Unknown & & & & & & \\
\hline & & Mid Santonian Conejo Formation, Boyacá, & & & & & & & \\
\hline \multirow[t]{2}{*}{ 320013-003 } & Eubrachyuran sp.. & Colombia & Hexagonal / hexagonal & 1.29 & 1.28 & 6.80 & 7.00 & 18.97 & 40.90 \\
\hline & & Campanian, Guadalupe Group, Boyacá, & & & & & & & \\
\hline 320010-002 & Eubrachyuran sp. & Colombia & Hexagonal / hexagonal & & & & & & \\
\hline \multicolumn{10}{|l|}{ Uncatalogued } \\
\hline specimen & Pseudothelphusidae sp. & Miocene, Panama & Hexagonal / hexagonal & & & & & & \\
\hline
\end{tabular}

